\title{
地下水ガバナンスに関する国内関連事例集*
}

中川 啓 ${ }^{1}$ ・八木信一 ${ }^{2} \cdot$ 石原成幸 $^{3} \cdot$ 蛯原雅之 $^{4} \cdot$ 遠藤崇浩 $^{5}$. 新貝文昭 ${ }^{6} \cdot$ 竹内真司 ${ }^{7} \cdot$ 中谷 仁 $^{8} \cdot$ 坂東和郎 $^{9} \cdot$ 平山利晶 ${ }^{10}$

\section{A collection of domestic case studies on groundwater governance activities in Japan}

\author{
Kei NAKAGAWA ${ }^{1}$, Shin-ichi YATSUKI ${ }^{2}$, Shigeyuki ISHIHARA ${ }^{3}$, Masayuki EBIHARA $^{4}$, \\ Takahiro ENDO ${ }^{5}$, Fumiaki SHINKAI ${ }^{6}$, Shinji TAKEUCHI ${ }^{7}$, Masashi NAKATANI $^{8}$, \\ Kazuro BANDO ${ }^{9}$ and Toshiaki HIRAYAMA ${ }^{10}$
}

\begin{abstract}
As one of the recent activities, JAGH (Japanese Association of Groundwater Hydrology) established the groundwater governance research group. It investigates the policies and sustainable groundwater use governance in relation to the Basic Plan on Water Cycle Policy. The research is conducted with a certain scope on social scientific aspects. The research group (Group C: 15 members) is manly focused on domestic case studies. Present work represents a study on 65 individual cases collected from 58 provinces. The case studies were compiled and characterized with some basic clustering criteria.
\end{abstract}

* 日本地下水学会2018年春期講演会で一部発表

1 長崎大学総合生産科学域（†852-8521 長崎県長崎市文教町1-14） Institute of Integrated Science and Technology, Nagasaki University

2 九州大学大学院経済学研究院（†819-0395 福岡県福岡市西区元岡744）

Faculty of Economics, Kyushu University

3 東京都庁（ ₹ 163-8001 東京都新宿区西新宿2-8-1）

Tokyo Metropolitan Government

4 株式会社建設技術研究所（１１03-8430 東京都中央区日本橋浜町3-21-1）

CTI Engineering Co., Ltd.

5 大阪府立大学現代システム科学域（†599-8531 大阪府堺市中区学園町1-1)

College of Sustainable System Sciences, Osaka Prefecture University

6 パシフィックコンサルタンツ株式会社（†101-8462＼cjkstart東京都千代田区神田錦町3-22）

Pacific Consultants Co., Ltd.

7 日本大学文理学部（†156-8550 東京都世田谷区桜上水3-25-40)

College of Humanities and Sciences, Nihon University

8 株式会社日さく（３30-0854＼cjkstart埼玉県さいたま市大宮区桜木町4-199-3）

Nissaku Co., Ltd.

9 株式会社興和（†950-0965 新潟県新潟市中央区新光町6-1）

Kowa Co., Ltd.

10 国際航業株式会社（干102-0085 東京都千代田区6-2)

Kokusai Kogyo Co., Ltd. 
地下水学会誌 第 62 巻第 2 号 $233 \sim 254(2020)$

Key Words: Groundwater governance, Case studies, Basic Plan on Water Cycle Policy, Basic Act on Water Cycle Policy, Sustainable groundwater use

\begin{abstract}
要旨
公益社団法人日本地下水学会では, 水循環基本計画に示されている多くの施策項目, 特に持続可能 な地下水の保全と利用に関わる「地下水ガバナンス」を中心とした調査・研究を, 社会科学的な観点 から行う「地下水ガバナンス等調査・研究グループ」を立ち上げ, 検討を行ってきた。この調査・研 究グループのうち, 国内関連事例を担当しているグループC として, 総勢15名のメンバーで活動に取 り組んできた。本稿では, そうした活動の中で整理した, 地下水ガバナンスに関する国内関連事例に ついてとりまとめたものについて資料として公表するものである。収集された事例は, 58 地域からの 65事例であり，いくつかの基本的な特性により分類を試みている。
\end{abstract}

キーワード : 地下水ガバナンス, 事例集, 水循環基本計画, 水循環基本法, 持続可能な地下水利用

\section{1.はじめに}

公益社団法人日本地下水学会では, 水循環基本 計画に示されている多くの施策項目，特に持続可 能な地下水の保全と利用に関わる「地下水ガバナ ンス」を中心とした調査・研究を, 社会科学的な 観点から行う「地下水ガバナンス等調査・研究グ ループ」を立ち上げ，検討を行ってきた。この調 查・研究グループのうち, 国内関連事例を担当 しているグループC（主査：八木信一・副査：中 川 啓）として, 総勢15名のメンバーで活動に取 り組んできた。

グループCに対する課題としては「国内先進 地域に扔ける地下水ガバナンスの事例と特色：構 築のプロセス」と，これを踏まえた「地下水ガバ ナンスにおける企業の役割」および「地下水ガバ ナンスにおける NGO, NPO の役割」が与えられ ていた。これを踏まえて，まずはメンバーがこれ まで関与してきた，あるいは興味を持ってきた事 例に関する情報の収集と共有化を進めるために地 下水保全の事例集の作成を行うことから始めた。 情報の収集にあたっては，グループCの主査が 「対象地域名（都道府県名・市町村名）」，「取組の 関係団体名」,「事例や取組」,「内容紹介および関 心事項」を主な提供項目として設定した。2017 年11月から開始し，2018年度末時点において計58 地域（65事例）が収集されており，グループのメ ンバー等で共有してきた。

\section{2. 事例の分類方法}

収集された事例は，58地域の65事例である。こ れについて, 環境省による地下水保全の事例集 （環境省，2015）との対応をつけながら，環境政 策が,「目的」,「手段」, および「主体」により構 成されること（植田，1996）などを勘案し，表 1 に示した五つの項目（「対象」,「目標」,「手段」, 「主体」，「基盤」）により，分類を行った。なお， 環境省による事例集では, 地下水保全に関する事 例を11の大項目に分類しており，それらは，(1)水 収支把握，(2)体制づくり，(3)地域連携，(4)保全計 画，(5)モタリング，66涵養，(7)管理目標，8資 金管理，(9)水文化の継承，(10地域づくり，(11)教育 と学習といった項目である。また, こうした分類 項目と類似のものとして, 地下水ガバナンスを評 価する方法として, 千葉（2019）により国際機関 による地下水ガバナンスプロジェクトの構成要素 が紹介されている。それらは,「アクター」,「法・ 規制・制度の枠組み」, 「目標・政策・計画」，「情報・ 知識」である。「アクター」は, 地下水の利用や 保全管理に直接・間接の利害関係を有する人々や 組織であるので,「主体」と似た性格と言える。 また「法・規制・制度の枠組み」は，慣習法・成 文法に関わらない，地下水に関連するあらゆる法 律に関するものとされている。ここでは「手段」 に近い性格のものと考えられる。「目標・政策 · 計画」は, 地下水ガバナンスの目標や原則, およ びそれらを実現していくための政策や計画にかか 
わるものとされており，ここでは「目標」と共に 「手段」にも関連する概念である。「情報・知識」 は, 地下水に関する様々な情報と知識の集積, お よびその共有・普及に関するものとされている。 ここでは，モニタリングなどの情報収集や得られ た情報の公開や学習といった「基盤」と関連する ものと位置づけられる。

\section{3. 事例の収集及び分類結果}

前章に示した五つの項目に沿って分類した結果 を表 2 に示す。本報で分類に適用した 5 項目につ いて，概要を述べると以下のようである。「対象」 は, 地盤沈下や地下水量減少（地下水位の低下） を抑制するための “水量” や, 工業活動や農業活 動に起因する地下水污染などの “水質”に関する ものなどがある。収集した事例の中では, “水量” が関係するものは66\%（43件）と多くの事例を占 めており，“水質”に関するものも35\%（23件） の事例があった。「目標」は, “計画”の中で示す 事例が多い。条例や規制で基準設定を行う場合も ある。54\% (35件) の事例が “計画”に関するも のであった。「手段」は, 先に述べたような条例 や規制を用いて, “水量”や “水質”に対して影 響を与えている主体の行動を直接的に変える「直 接的手段」や，ゾーニングや経済的手法によって これらの主体の行動を誘導する「間接的手段」が ある。32\%(21件)が“条例”によるものであった。 「主体」は，これまでは“行政”が大きな位置づ
けを占めていたが，計画の策定や実施，モニタリ ングなどにおいて，それ以外の多様な主体によっ て構成される協議会を設ける場合が多くなってい る。また行政についても越境する流域に応じた広 域連携といったケースも見られる。こうした他自 治体と連携した取り組みについては, 千葉 (2019) の調査によると，11.5\%（223件中26件）が実施 済みあるいは実施中である。収集した事例の中で は, 62\% (40件) が“行政”を主体とするもので, 37\% (24件) は “協議会”を主体とするものであっ た。「基盤」は，モニタリングなどの科学的知見 の蓄積やそれに基づく情報公開および学習と定義 されるものである。29\%（19件）は, “モニタリ ング”に関するものであった。また, 地下水を公 水・共有資源などと規定しているものは $32 \%(21$ 件）であった。

\section{4. おわりに}

本稿では，国内における地下水ガバナンスに関 連すると考えられる事例を収集し,「対象」,「目 標」,「手段」,「主体」,「基盤」の 5 項目を設定し て分類し，事例集として整理を行った。この分類 項目は, 地下水保全のための環境政策の観点から 設定したものである。地下水ガバナンスの観点か ら当初，論点整理を試みた事例については，八 木・中川（2018）を参照されたい。またグループ Cでは, いくつかの事例を取り上げつつ, 地下水 ガバナンスの動態を分析するため, その論点・枠

\section{表 1 国内関連事例の分類項目}

Table 1 Classified items for domestic case studies related to groundwater governance.

\begin{tabular}{|c|c|c|}
\hline 分類 & 内容 & 環境省事例集との対応関係 \\
\hline 対象 & $\begin{array}{l}\text { 水量（地盤沈下を含む）, 水質, 水環境, 水 } \\
\text { 循環，水文化など }\end{array}$ & (6涵養（対象との関係で), 99水文化の継承 \\
\hline 目標 & 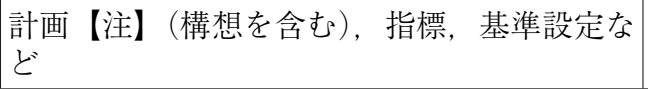 & (4)保全計画, 7)管理目標 \\
\hline 手段 & $\begin{array}{l}\text { 条例・要綱, ゾーニング，経済的手法，まち } \\
\text { づくり，地域ブランドなど }\end{array}$ & (6)涵養（事業との関係で), 8資金管理，10地域づくり \\
\hline 主体 & 行政, 協議会, 広域連携など & (2)体制づくり, (3)地域連携 \\
\hline 基盤 & $\begin{array}{l}\text { モニタリング, 水収支把握, 技術開発・導 } \\
\text { 入, 情報公開, 学習など }\end{array}$ & (1)水収支把握，(5)モニタリング，(11教育と学習 \\
\hline
\end{tabular}

【注】計画については「手段」も一部で関連 
地下水学会誌 第 62 巻第 2 号 $\quad 233 \sim 254$ (2020)

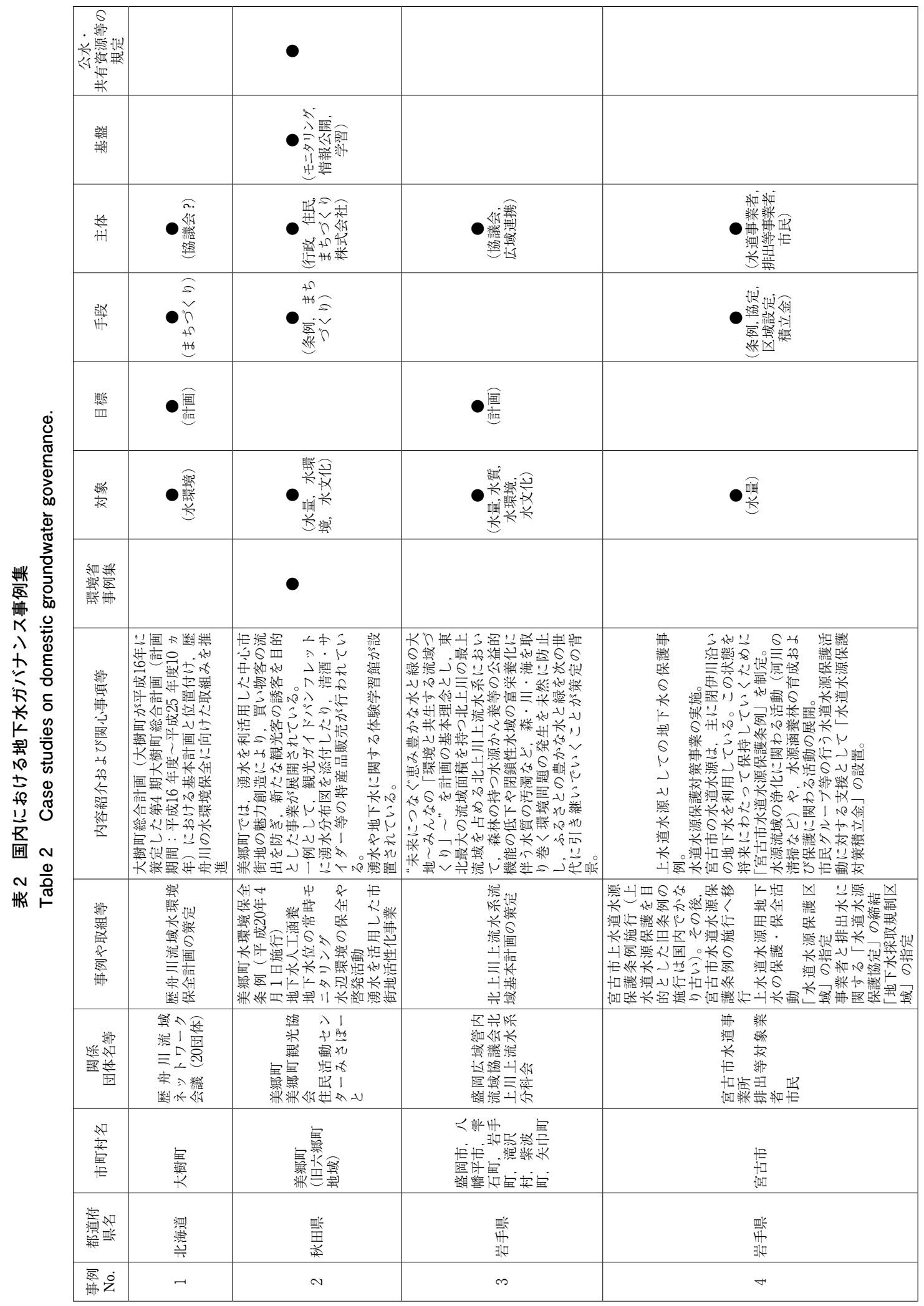




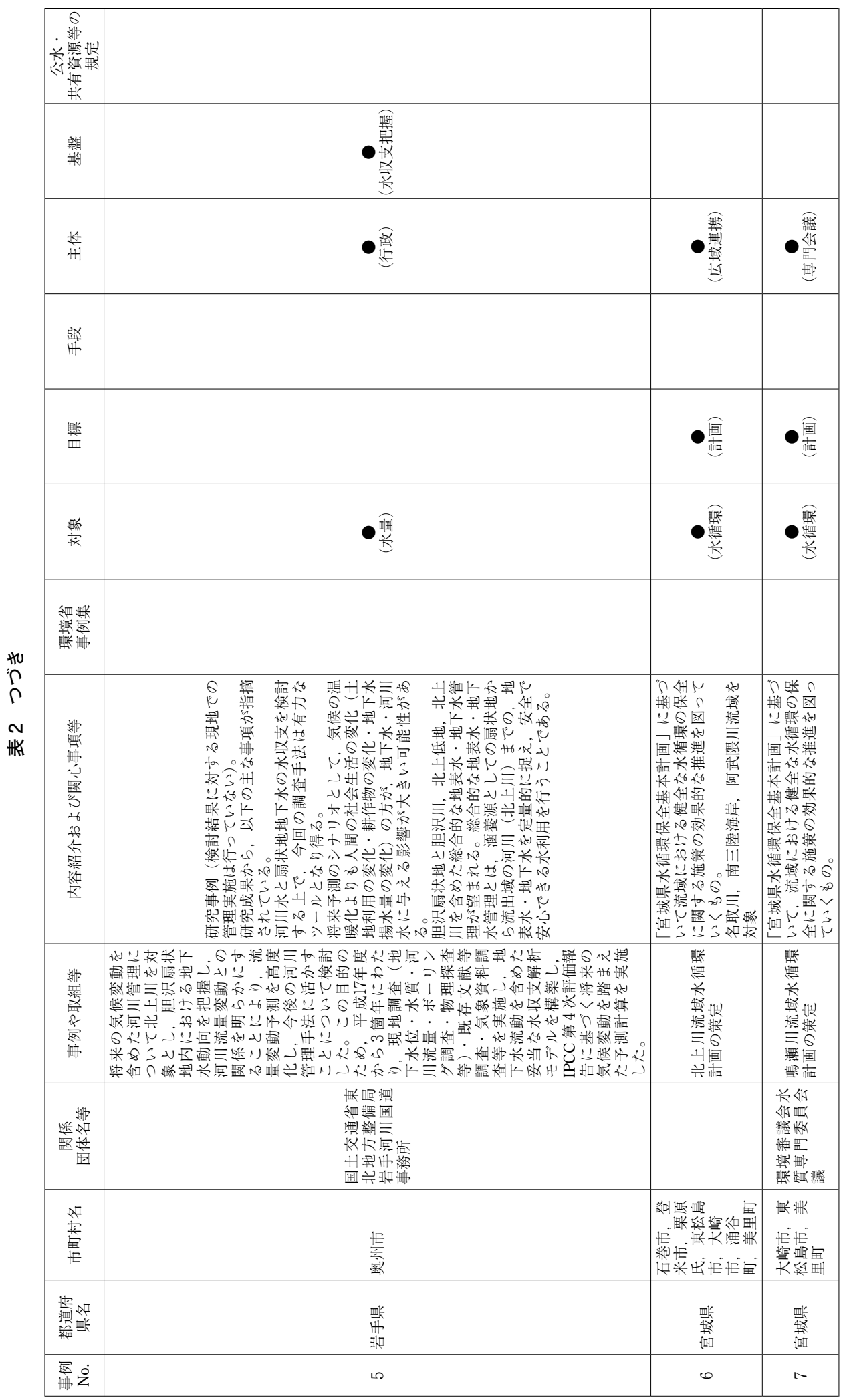


地下水学会誌 第 62 巻第 2 号 $\quad 233 ＼mathrm{~ 254 （ 2020 ） ~}$

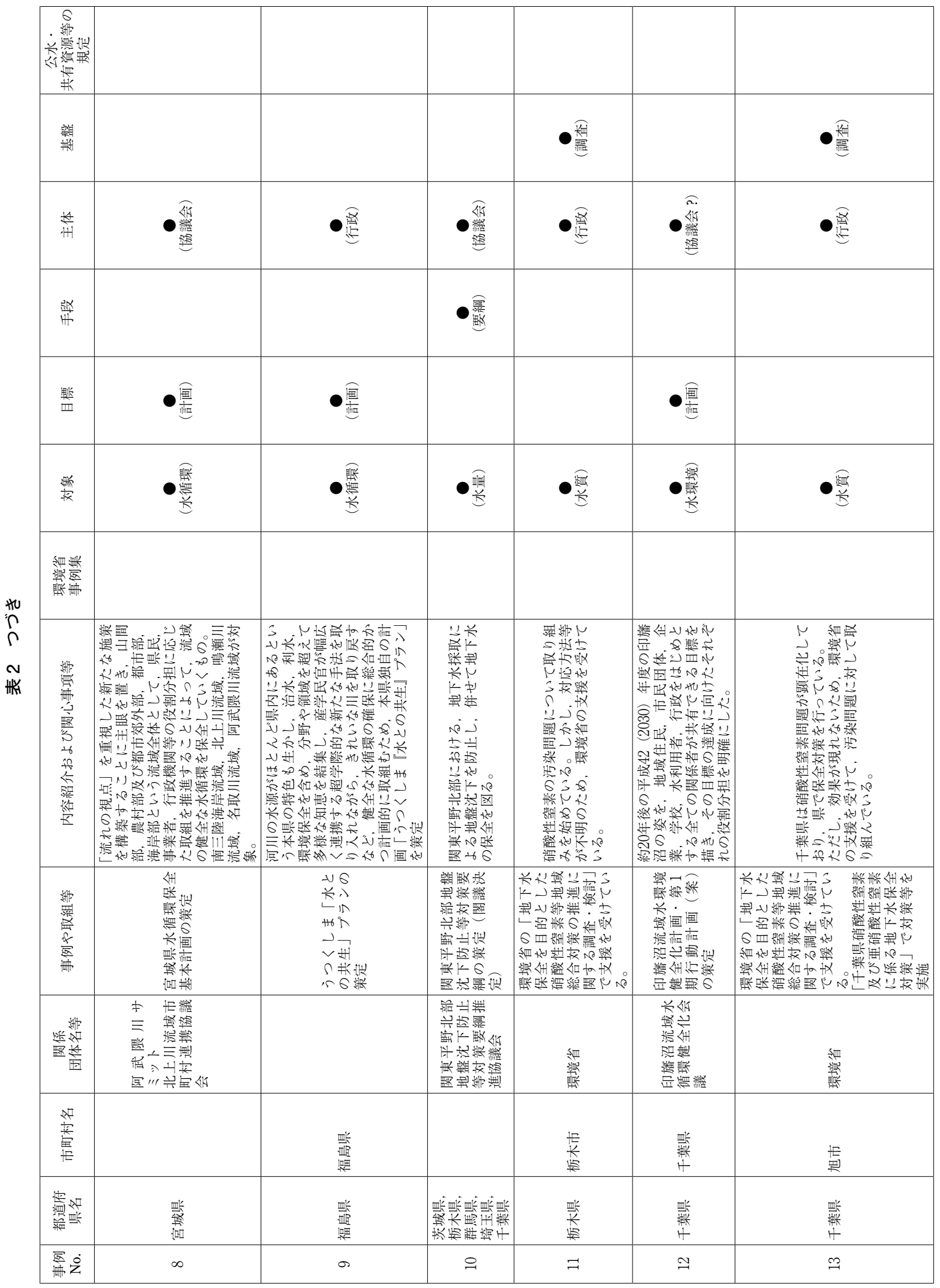


地下水学会誌 第 62 巻第 2 号 $\quad 233 \sim 254$ (2020)

\begin{tabular}{|c|c|c|}
\hline 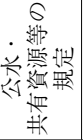 & & 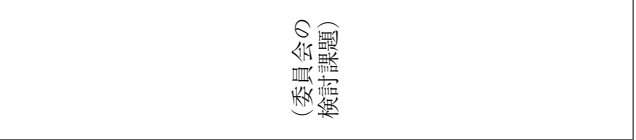 \\
\hline $\begin{array}{l}\text { 辣 } \\
\text { 形 }\end{array}$ & & 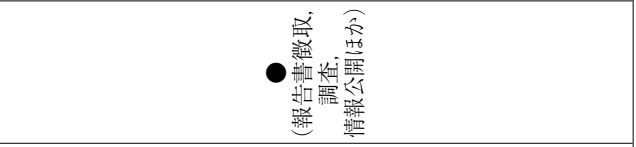 \\
\hline$\frac{\Delta}{H+1}$ & 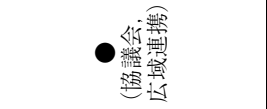 & 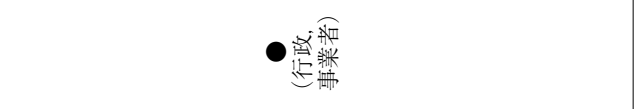 \\
\hline 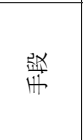 & & 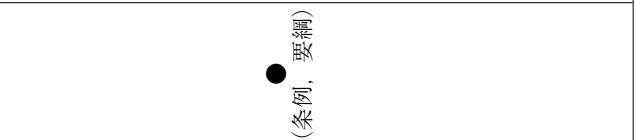 \\
\hline 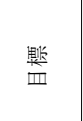 & 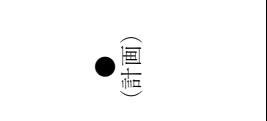 & 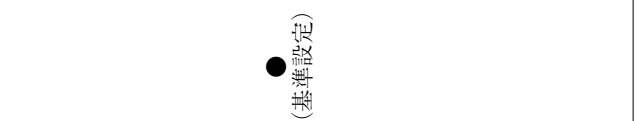 \\
\hline 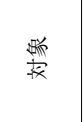 & - & 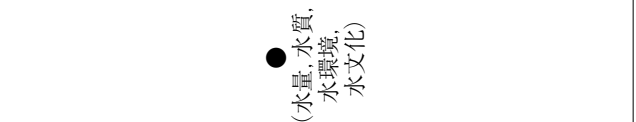 \\
\hline 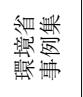 & & \\
\hline 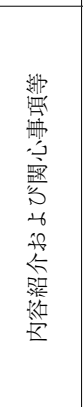 & 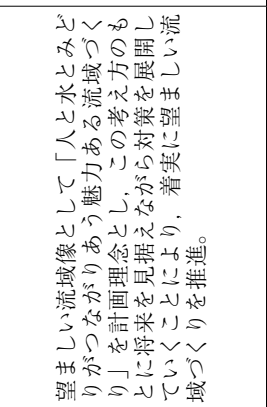 & 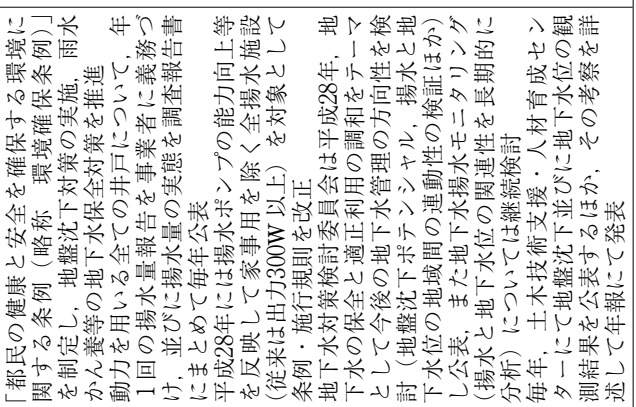 \\
\hline 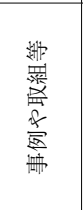 & 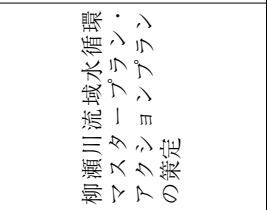 & 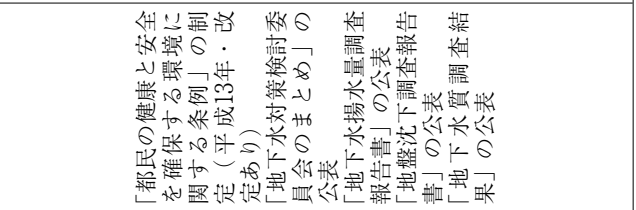 \\
\hline 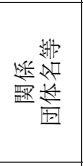 & 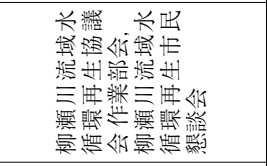 & 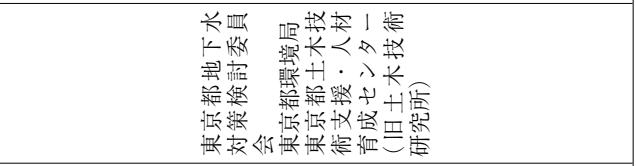 \\
\hline 嵉 & 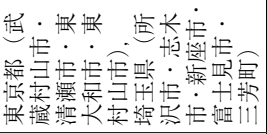 & 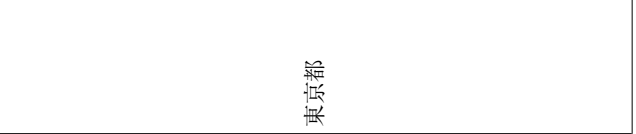 \\
\hline 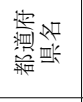 & 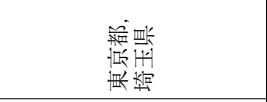 & 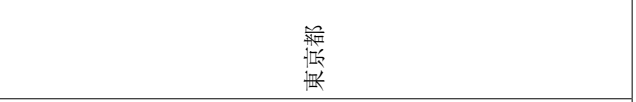 \\
\hline 蛋方 & $\exists$ & $\stackrel{2}{2}$ \\
\hline
\end{tabular}


地下水学会誌 第 62 巻第 2 号 $\quad 233 ＼mathrm{~ 254 （ 2020 ） ~}$

\begin{tabular}{|c|c|c|}
\hline 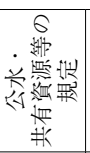 & & • \\
\hline 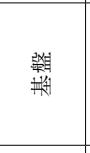 & 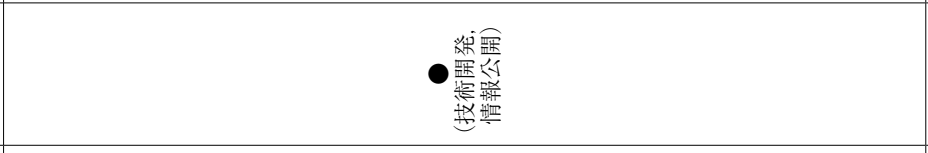 & 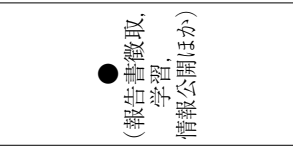 \\
\hline$\frac{-4}{i+1}$ & 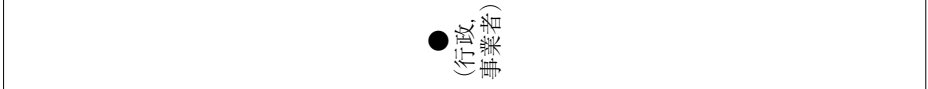 & 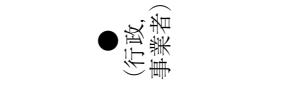 \\
\hline 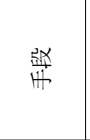 & 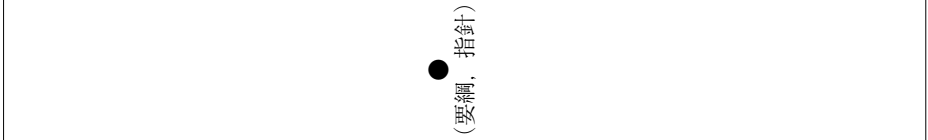 & - \\
\hline 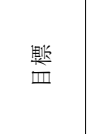 & 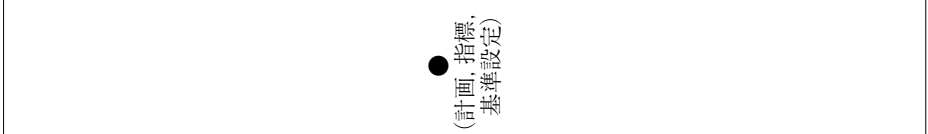 & 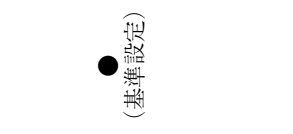 \\
\hline 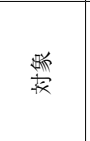 & 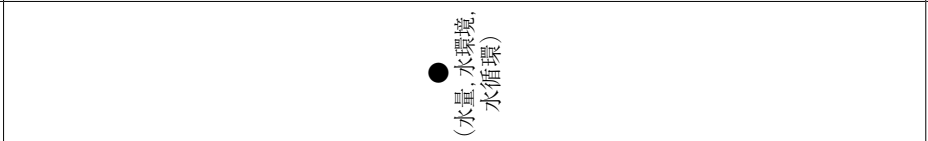 & 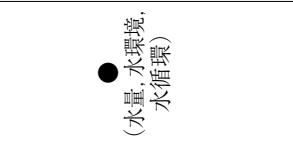 \\
\hline 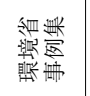 & & \\
\hline 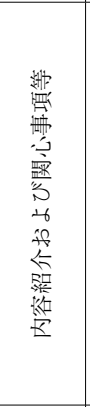 & 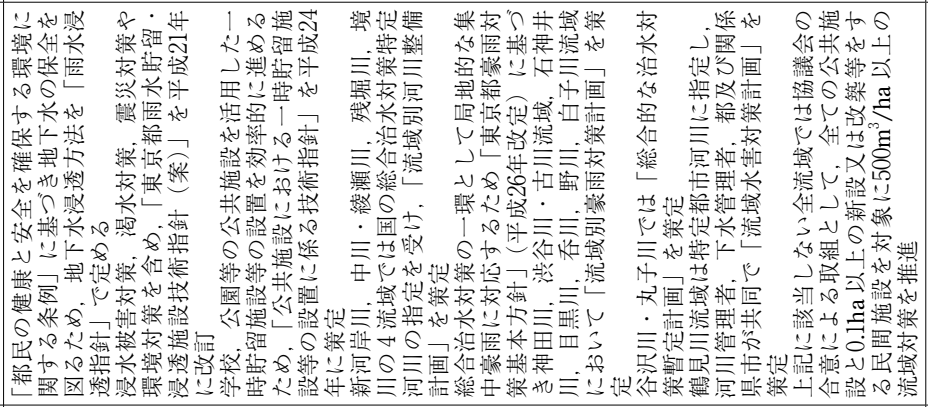 & 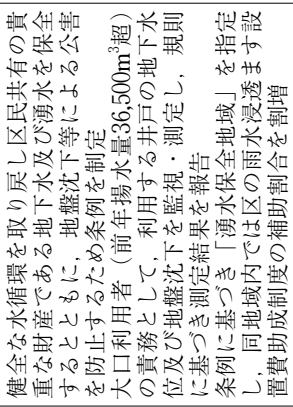 \\
\hline 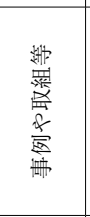 & 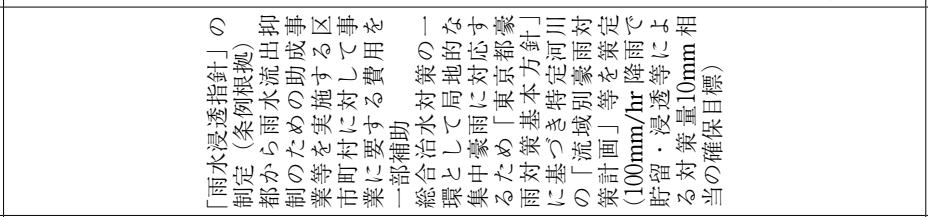 & 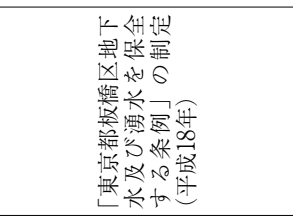 \\
\hline 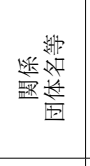 & 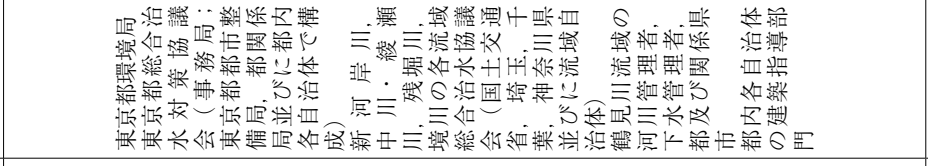 & 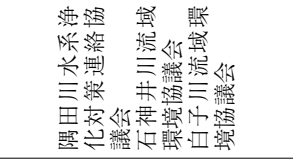 \\
\hline 崖 & 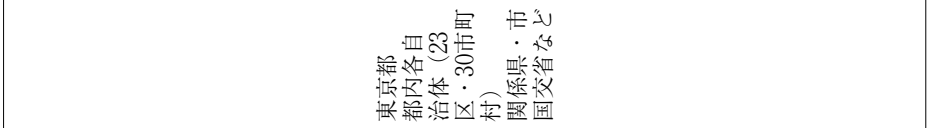 & 㐫 \\
\hline 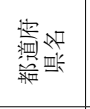 & 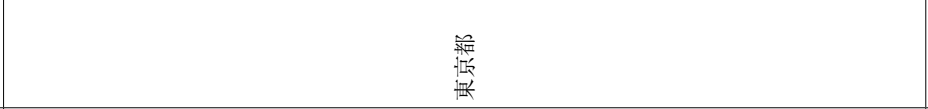 & 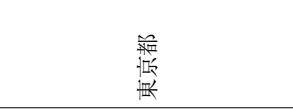 \\
\hline$\underset{8}{g}$ & $\mathscr{2}$ & 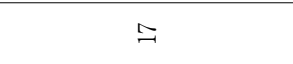 \\
\hline
\end{tabular}


地下水学会誌 第 62 巻第 2 号 $\quad 233 \sim 254$ (2020)

\begin{tabular}{|c|c|c|c|}
\hline 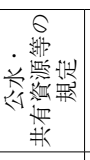 & • & • & \\
\hline 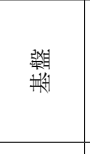 & 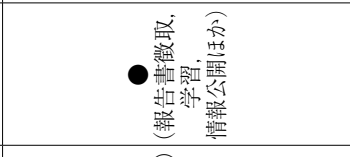 & 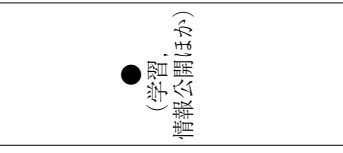 & 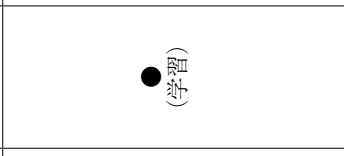 \\
\hline$\stackrel{H}{H}$ & • & 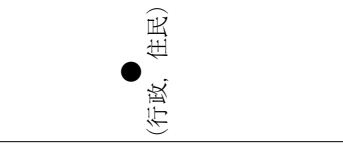 & 一叒 \\
\hline 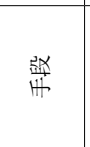 & 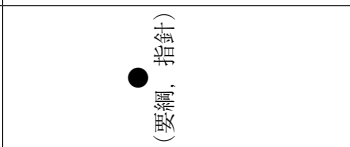 & 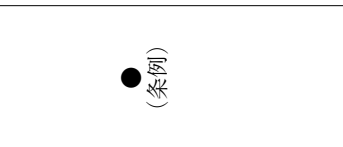 & \\
\hline $\begin{array}{l}\text { 政 } \\
\text { 留 }\end{array}$ & 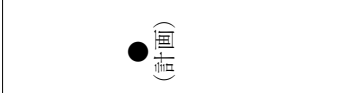 & •㾞 & • 霆 \\
\hline 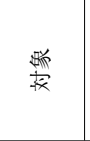 & 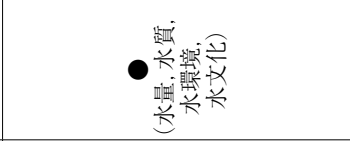 & 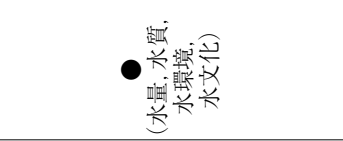 & 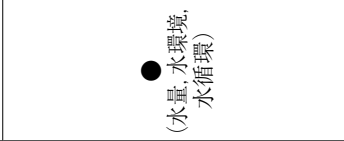 \\
\hline 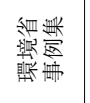 & & & • \\
\hline 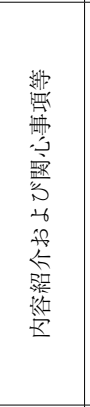 & 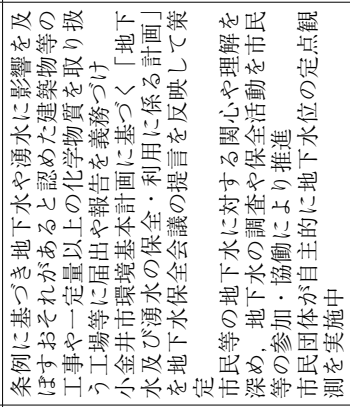 & 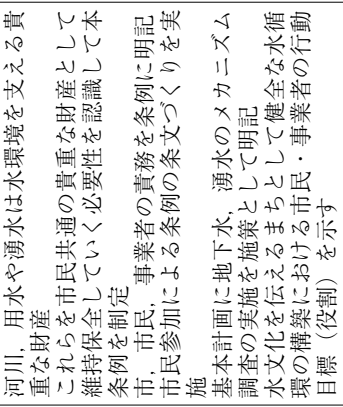 & 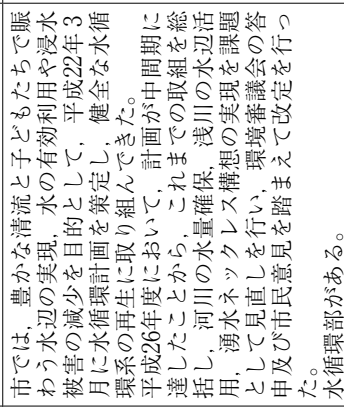 \\
\hline 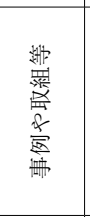 & 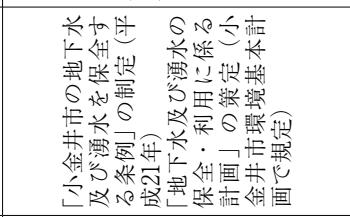 & 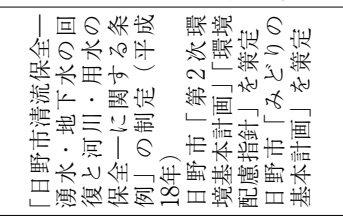 & 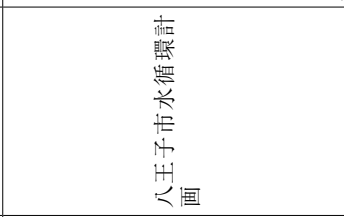 \\
\hline 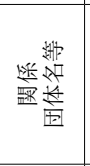 & 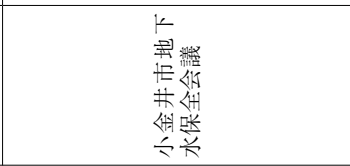 & & \\
\hline 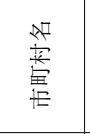 & 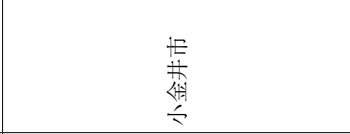 & 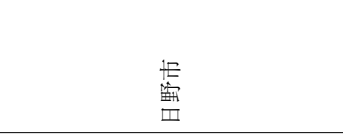 & $\begin{array}{l}\text { 禁 } \\
\text { 龺 } \\
2\end{array}$ \\
\hline 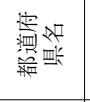 & 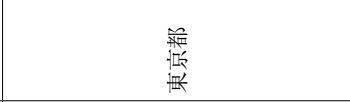 & 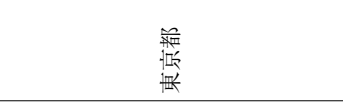 & 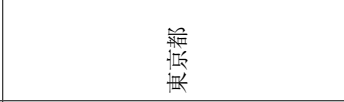 \\
\hline 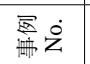 & $\stackrel{\infty}{-}$ & 9 & จ \\
\hline
\end{tabular}


地下水学会誌 第 62 巻第 2 号 $\quad 233 ＼mathrm{~ 254 （ 2020 ） ~}$

\begin{tabular}{|c|c|c|c|c|}
\hline 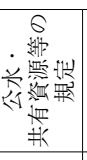 & & $\bullet$ & • & • \\
\hline $\begin{array}{l}\text { 溯 } \\
\text { 形 }\end{array}$ & & & & \\
\hline 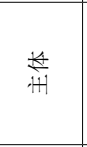 & 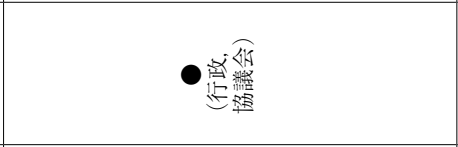 & • & 一叠 & 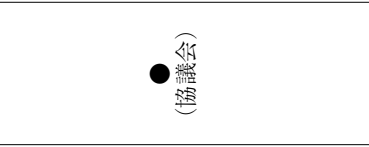 \\
\hline 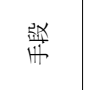 & & 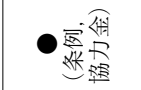 & & \\
\hline 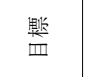 & 霆 & & ○熏 & 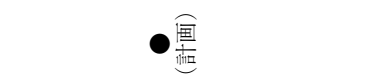 \\
\hline 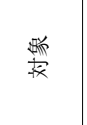 & 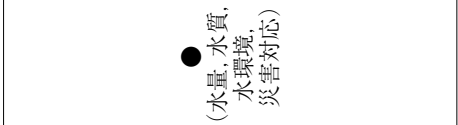 & ○些 & 㹂 & 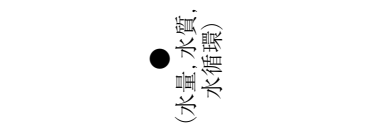 \\
\hline 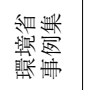 & & & • & \\
\hline 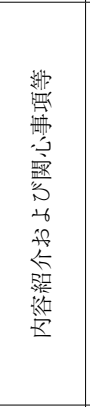 & 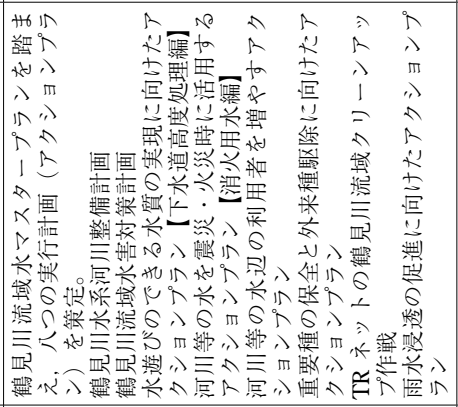 & 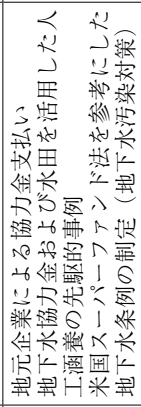 & 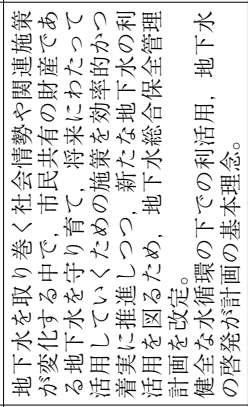 & 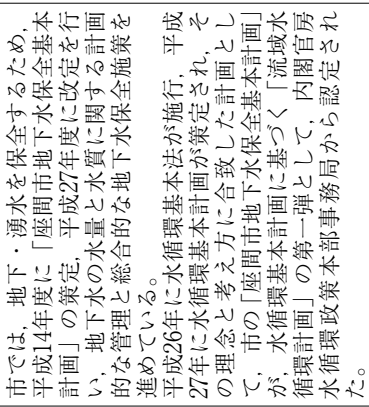 \\
\hline 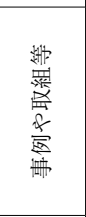 & 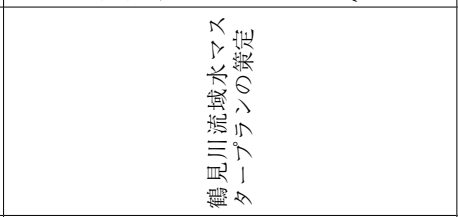 & 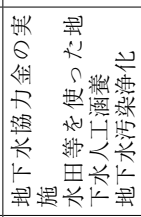 & 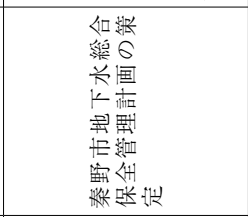 & 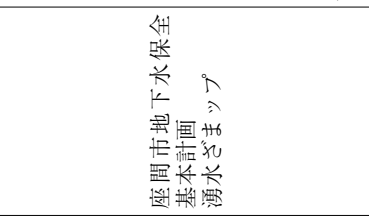 \\
\hline 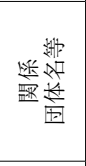 & 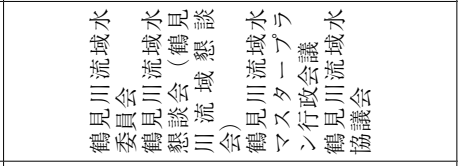 & 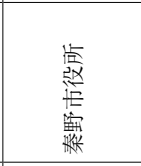 & & 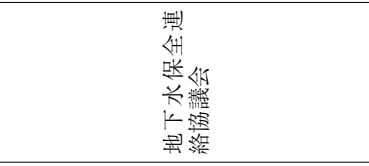 \\
\hline 㝣 & & 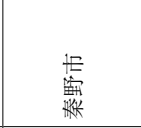 & $\begin{array}{l}\text { 監 } \\
\text { 粎 }\end{array}$ & $\begin{array}{l}\text { 監 } \\
\text { 邀 }\end{array}$ \\
\hline 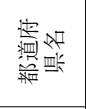 & 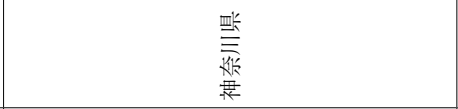 & 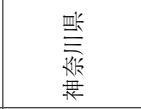 & 㹂 & 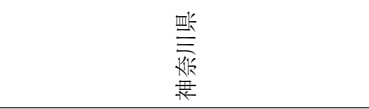 \\
\hline 尽完 & $\vec{N}$ & จュ & $\approx \widehat{N}$ & $\approx$ \\
\hline
\end{tabular}


地下水学会誌 第 62 巻第 2 号 $\quad 233 \sim 254$ (2020)

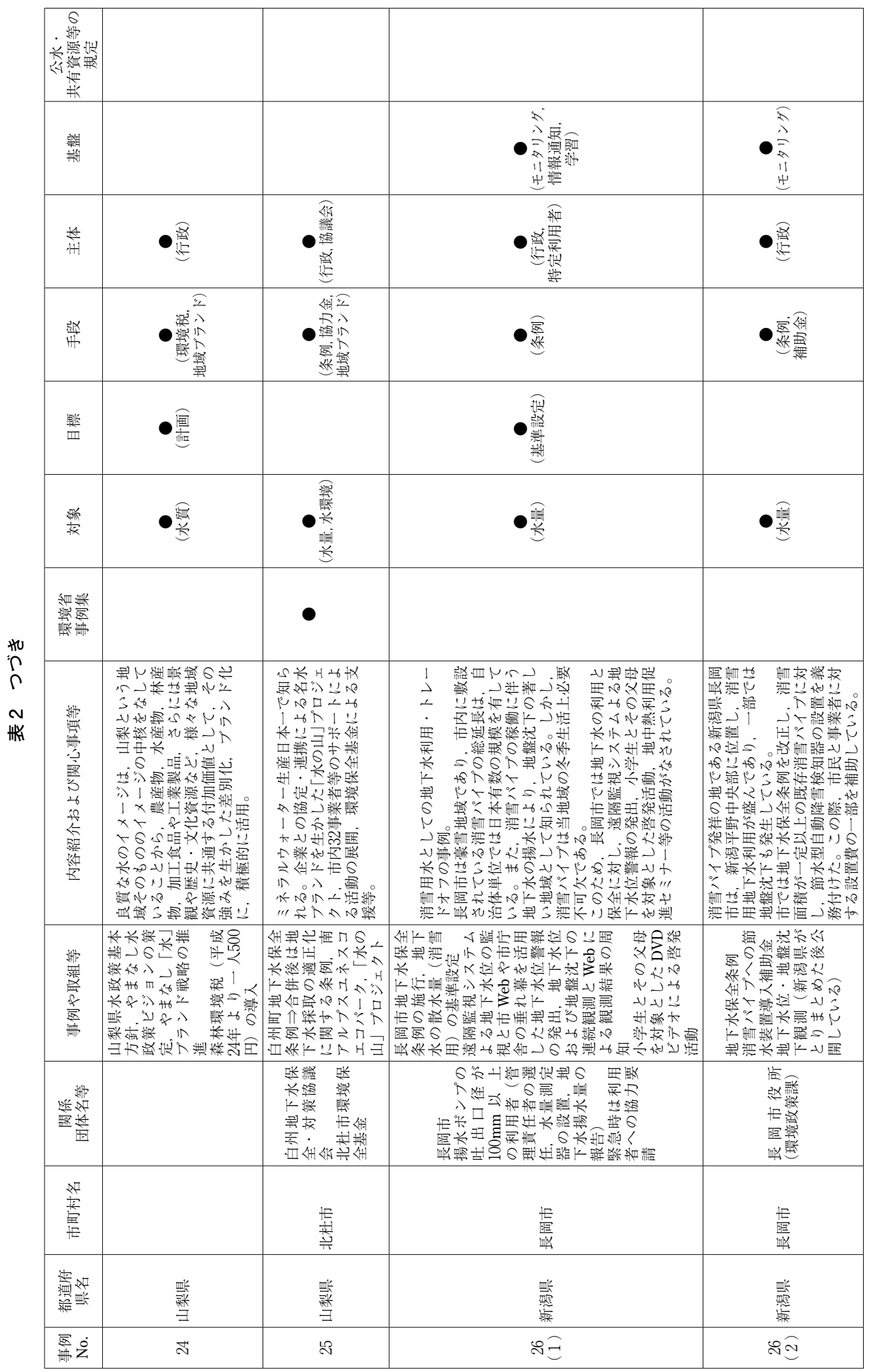


地下水学会誌 第 62 巻第 2 号 $\quad 233 ＼mathrm{~ 254 （ 2020 ） ~}$

\begin{tabular}{|c|c|c|c|c|}
\hline 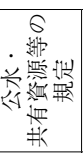 & & & & \\
\hline $\begin{array}{l}\text { 獸 } \\
\text { 形 }\end{array}$ & 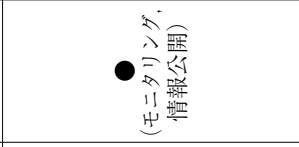 & 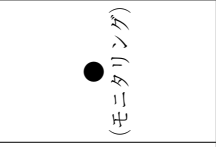 & 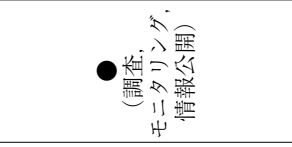 & 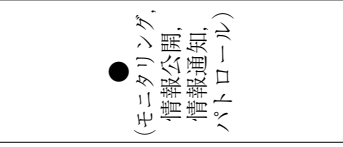 \\
\hline$\frac{4}{i+1}$ & 虂 & ・歮 & 一叒 & 一敠 \\
\hline$\frac{\frac{\mathrm{g} x}{\mathrm{~m}}}{\mathrm{H}}$ & • & 施 & 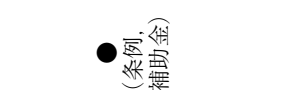 & - 㑒 \\
\hline 槛 & & & & 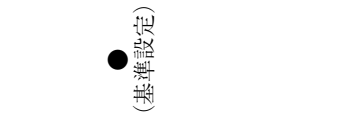 \\
\hline 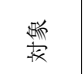 & ○咩 & ○哭 & ○䟛 & ○变 \\
\hline 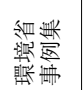 & & & & \\
\hline 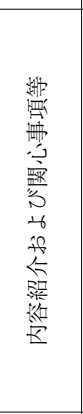 & 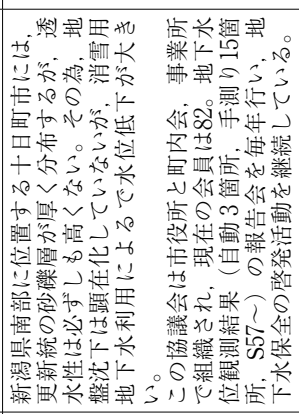 & 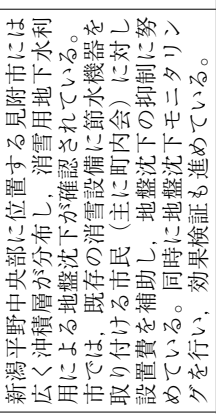 & 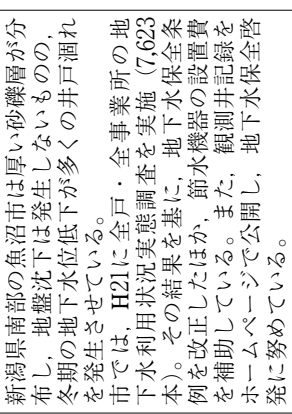 & 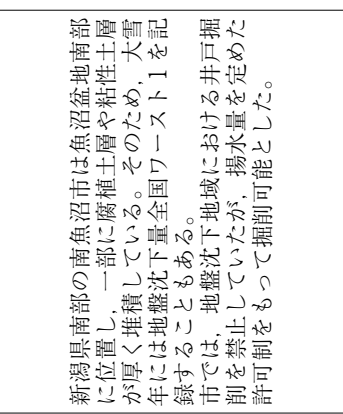 \\
\hline 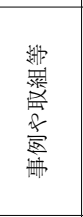 & 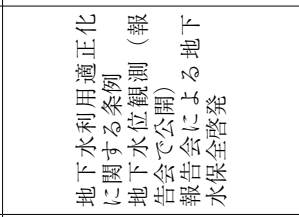 & 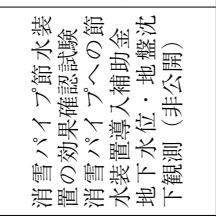 & 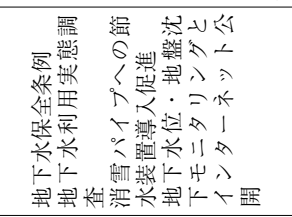 & 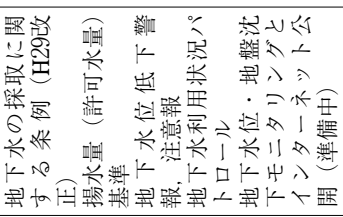 \\
\hline 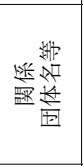 & 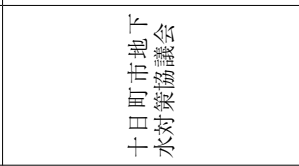 & 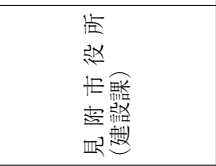 & 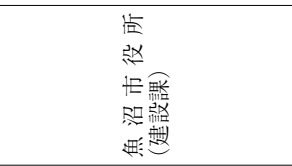 & 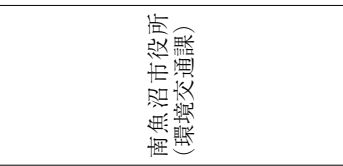 \\
\hline 窟 & $\begin{array}{l}\text { 抟 } \\
+ \\
+ \\
\end{array}$ & 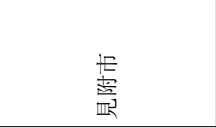 & 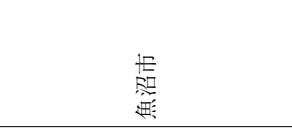 & 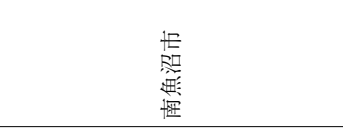 \\
\hline 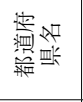 & 贜 & $\begin{array}{l}\text { 媐 } \\
\text { 缶 }\end{array}$ & 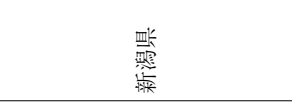 & $\begin{array}{l}\text { 媐 } \\
\text { 涪 }\end{array}$ \\
\hline 曐安 & $\lesssim$ & $\stackrel{\sim}{\sim}$ & 83 & в \\
\hline
\end{tabular}




\begin{tabular}{|c|c|c|c|c|c|}
\hline 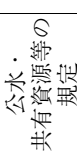 & & & - & - & \\
\hline 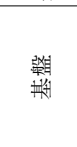 & 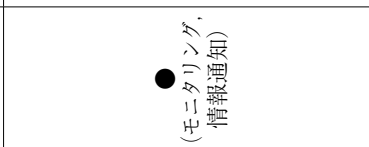 & 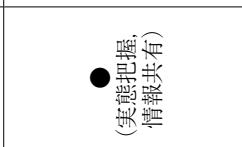 & & & 贫 \\
\hline$\frac{H}{H+1}$ & 一啥 & • & 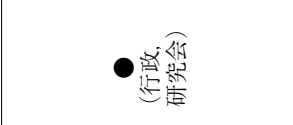 & ○営緍 & 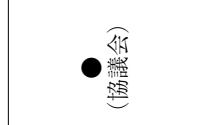 \\
\hline$\frac{\mathrm{dx}}{\mathrm{d}}$ & 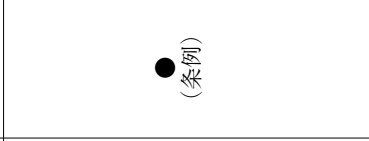 & & 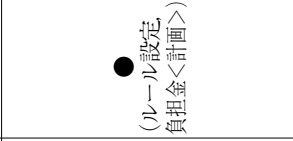 & & 竞命 \\
\hline 笽 & & & 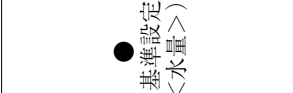 & ○舞 & \\
\hline 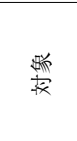 & ○䂹 & ○啨 & • & • & ○哭 \\
\hline 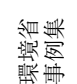 & & & • & • & \\
\hline 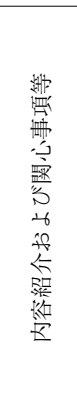 & 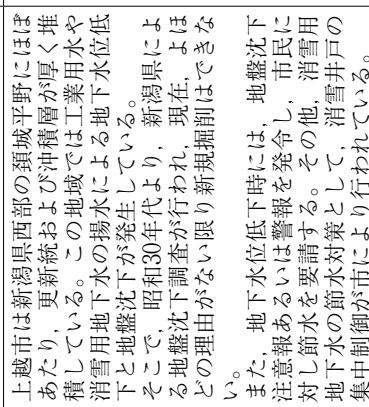 & 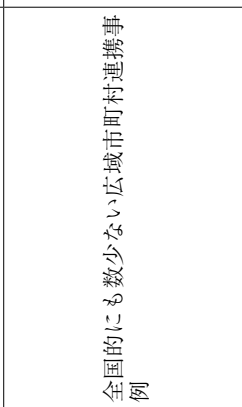 & 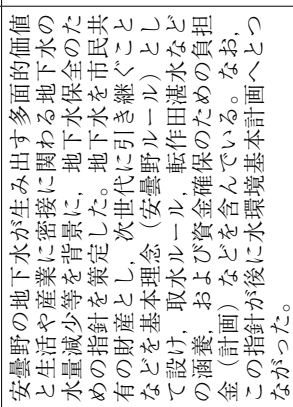 & 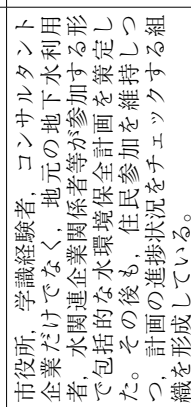 & 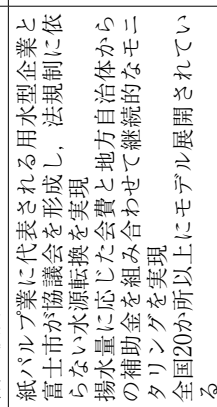 \\
\hline 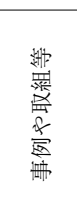 & 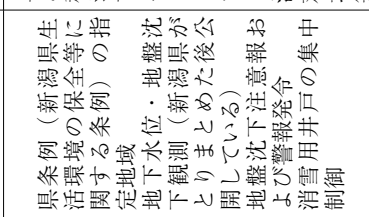 & 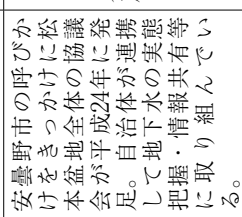 & 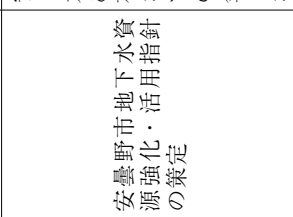 & 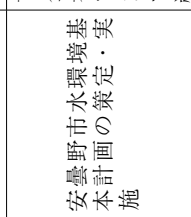 & 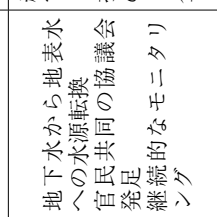 \\
\hline 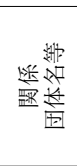 & 点 & 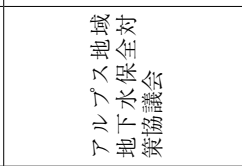 & 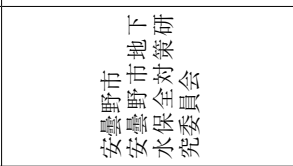 & 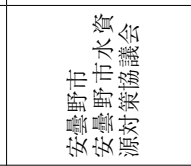 & 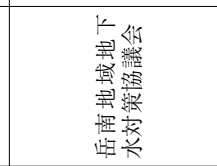 \\
\hline 暨 & 点热 & 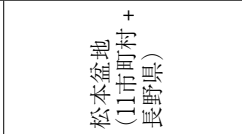 & 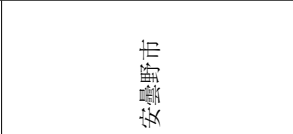 & 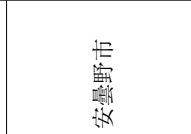 & 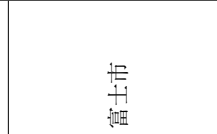 \\
\hline 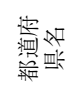 & 噔 & $\begin{array}{l}\text { 零 } \\
\text { 霞 }\end{array}$ & 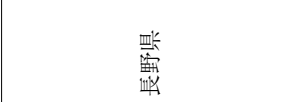 & 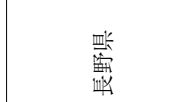 & 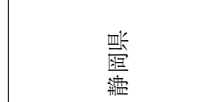 \\
\hline $\begin{array}{l}\text { 蛋家 } \\
\end{array}$ & $\vec{m}$ & న్ల & 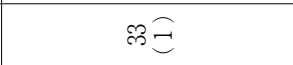 & $m \widehat{m}$ & ले \\
\hline
\end{tabular}


地下水学会誌 第 62 巻第 2 号 $\quad 233 ２ 54$ (2020)

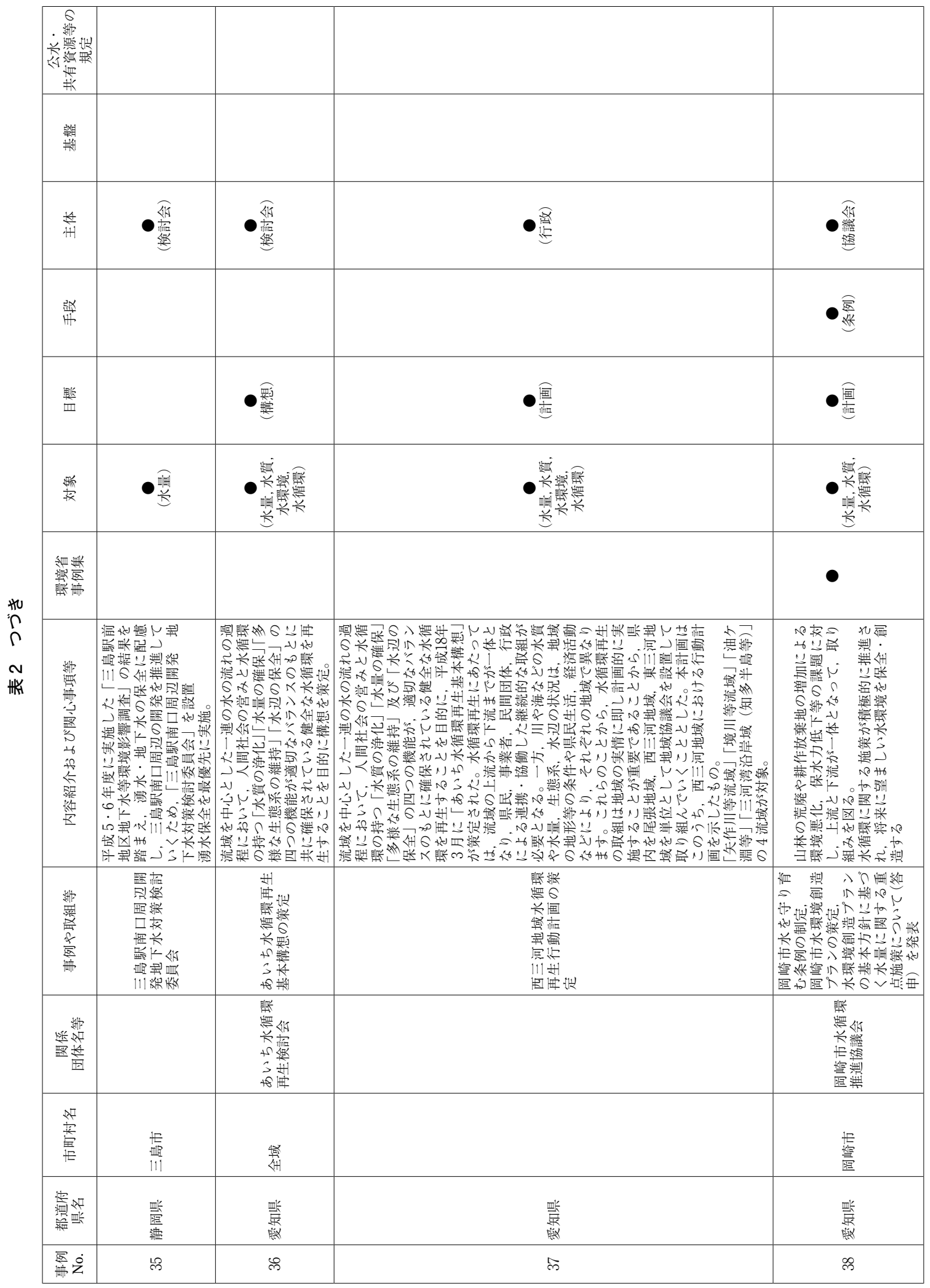




\begin{tabular}{|c|c|c|c|c|c|c|}
\hline 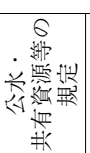 & & & & - & • & 0 \\
\hline 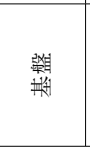 & & & & 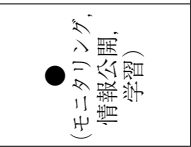 & & 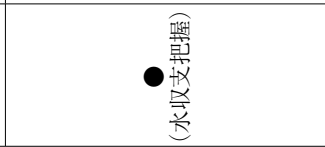 \\
\hline$\frac{H}{H}$ & 霆 & 众 & 一叒 & ・傩 & 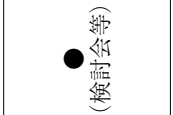 & 一啥 \\
\hline$\frac{\frac{a x}{H}}{H}$ & & 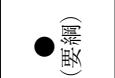 & & & & \\
\hline 盘 & 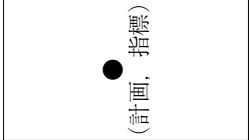 & & • 重 & 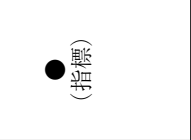 & 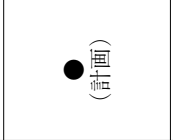 & -霆 \\
\hline 晒 & - 暨 & ○哭 & - 暨 & 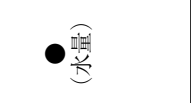 & - 亭 & ・曁 \\
\hline 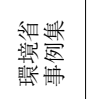 & $\bullet$ & & & $\bullet$ & • & • \\
\hline 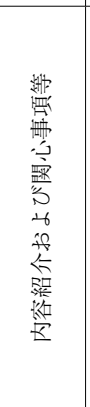 & 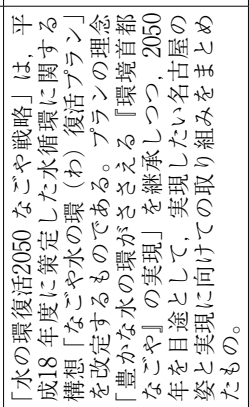 & 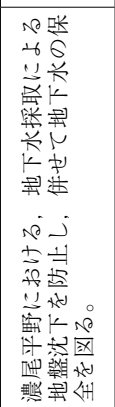 & 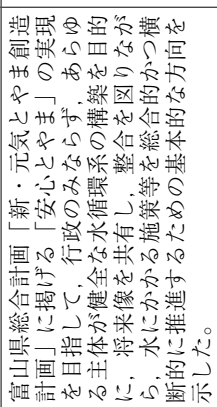 & 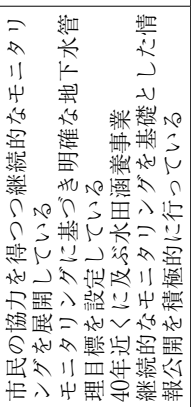 & 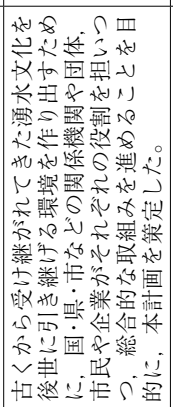 & 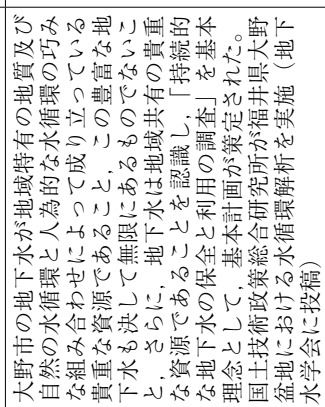 \\
\hline 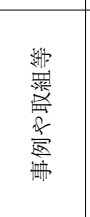 & 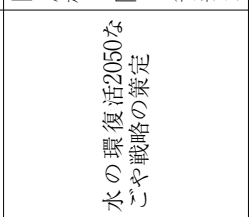 & 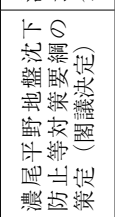 & 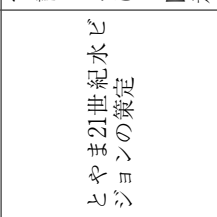 & 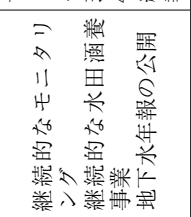 & 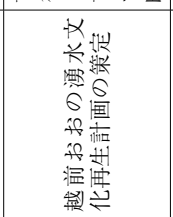 & 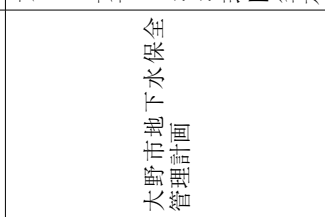 \\
\hline 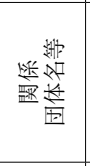 & 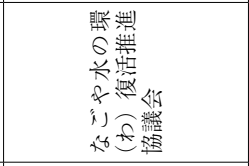 & 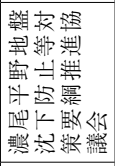 & & 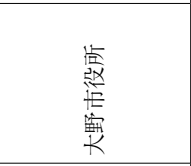 & 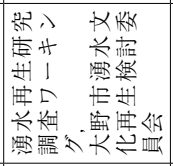 & 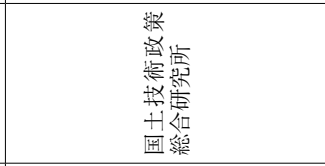 \\
\hline 諎 & 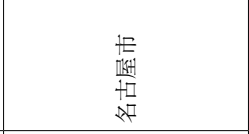 & & 䇾 & 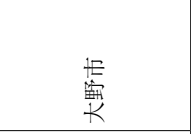 & 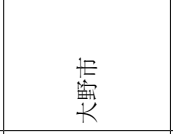 & 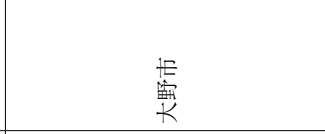 \\
\hline 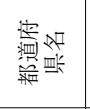 & 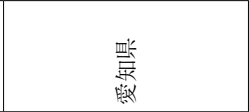 & 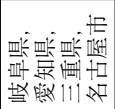 & 紫 & 䈉 & 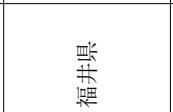 & 紫 \\
\hline 蛋家 & கి & or & $F$ & ช્ & พָล & স্ণু \\
\hline
\end{tabular}


地下水学会誌 第 62 巻第 2 号 $\quad 233 ２ 54$ (2020)

\begin{tabular}{|c|c|c|c|c|}
\hline 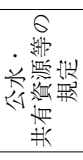 & • & • & & \\
\hline 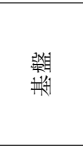 & ○䬺 & 会 & & \\
\hline$\frac{-4}{i+1}$ & 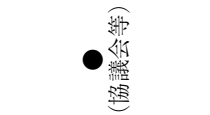 & 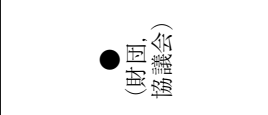 & 一㤟 & 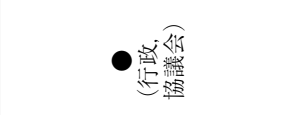 \\
\hline 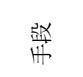 & & • & & • \\
\hline 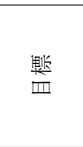 & & & 霆 & • \\
\hline 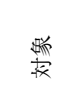 & - 咅 & 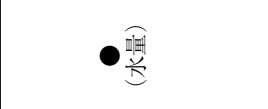 & 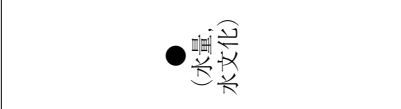 & 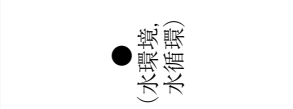 \\
\hline 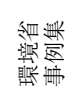 & • & & & • \\
\hline 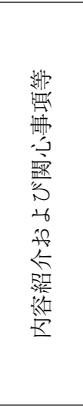 & 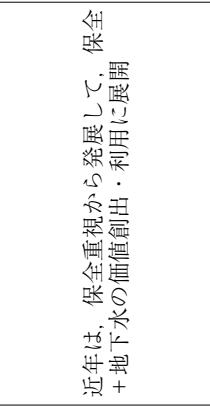 & 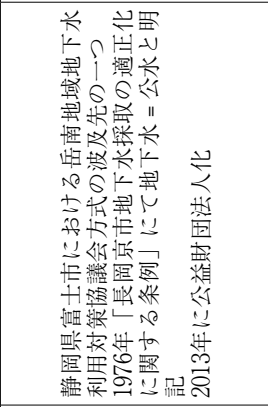 & 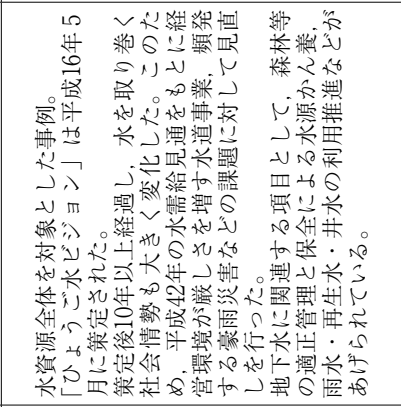 & 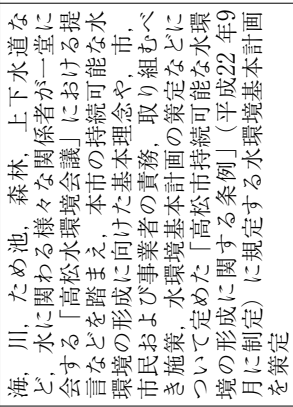 \\
\hline 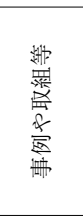 & 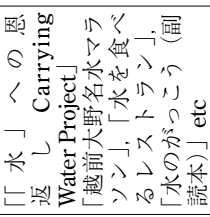 & 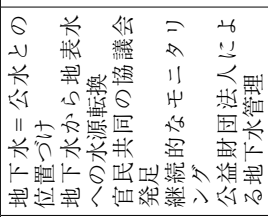 & 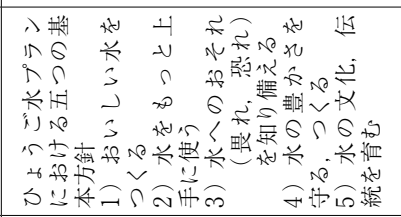 & 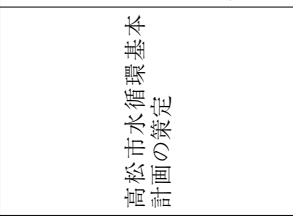 \\
\hline 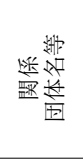 & 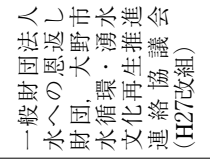 & 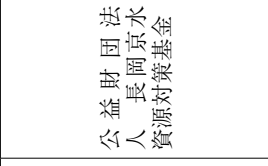 & 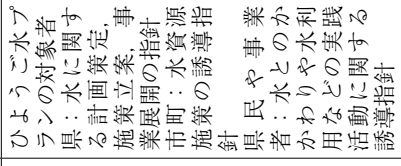 & 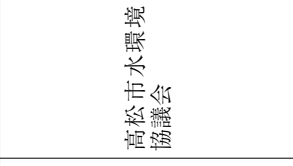 \\
\hline 㝣 & 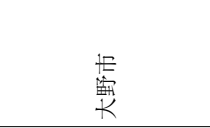 & 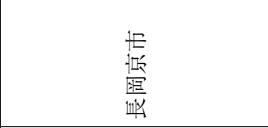 & 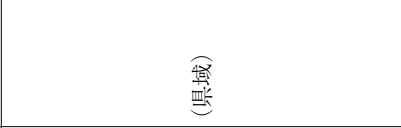 & 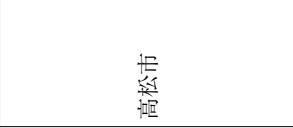 \\
\hline 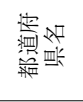 & 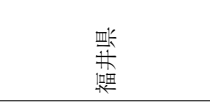 & 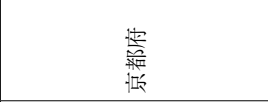 & $\begin{array}{l}\text { 監 } \\
\text { 宸 }\end{array}$ & $\underset{\text { 筷 }}{=}$ \\
\hline 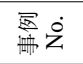 & भૈક & $\Re$ & 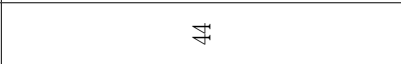 & \& \\
\hline
\end{tabular}


地下水学会誌 第 62 巻第 2 号 $\quad 233 \sim 254$ (2020)

\begin{tabular}{|c|c|c|c|}
\hline 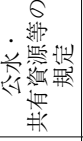 & $\bullet$ & • & \\
\hline $\begin{array}{l}\text { 辣 } \\
\text { 形 }\end{array}$ & • & & \\
\hline 湈 & 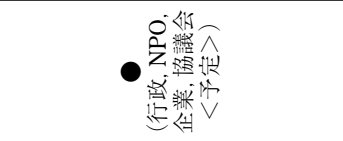 & • 㕛 & 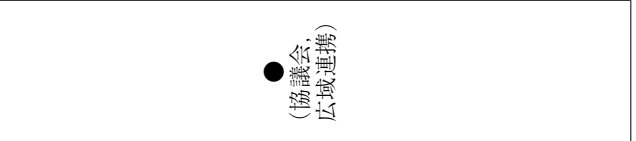 \\
\hline 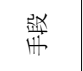 & • 棥 & & \\
\hline 啙 & 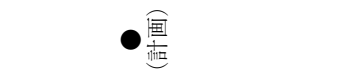 & ○霆 & • \\
\hline 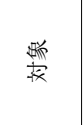 & ・觜点 & & 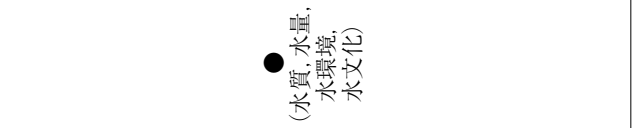 \\
\hline 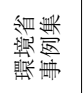 & & & \\
\hline 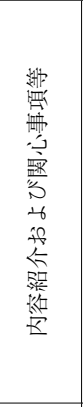 & 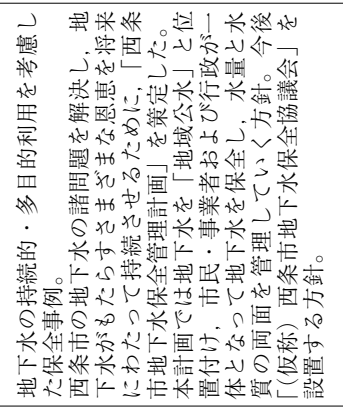 & & 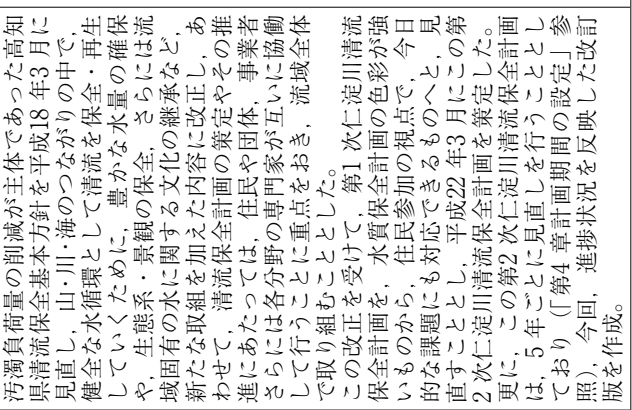 \\
\hline 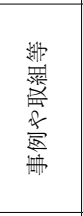 & 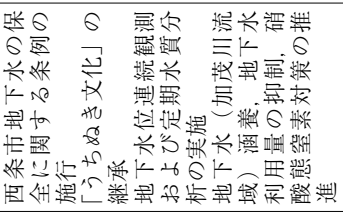 & 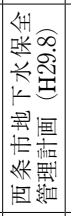 & 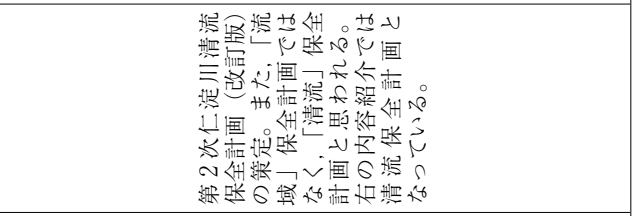 \\
\hline 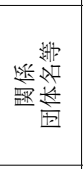 & 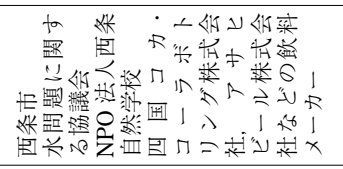 & 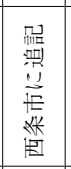 & 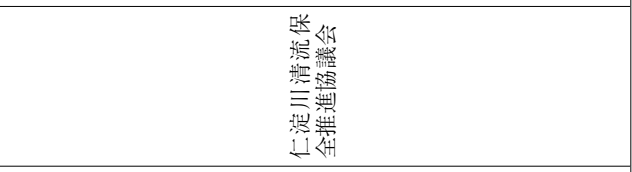 \\
\hline 㘶 & $\begin{array}{l}\text { 鹿 } \\
\text { 资 }\end{array}$ & & 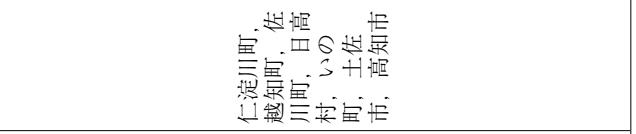 \\
\hline 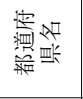 & 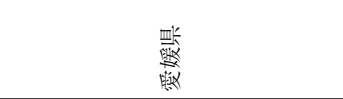 & 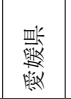 & $\begin{array}{l}\text { 箭 } \\
\text { 怔 }\end{array}$ \\
\hline 蛋方 & $\mathscr{F}=$ & \&্ত & F \\
\hline
\end{tabular}


地下水学会誌 第 62 巻第 2 号 $\quad 233 ２ 54$ (2020)

\begin{tabular}{|c|c|c|c|c|}
\hline 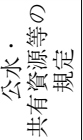 & & & & \\
\hline 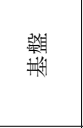 & & - & & \\
\hline$\frac{4}{H}$ & 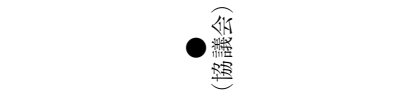 & 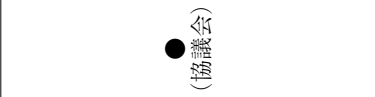 & 茛 & • 叠 \\
\hline 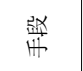 & - 金 & 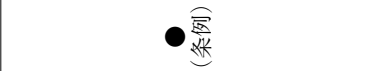 & & 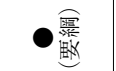 \\
\hline 槛 & & & 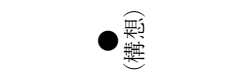 & \\
\hline 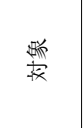 & 高变 & • & • 需 & ○嘼 \\
\hline 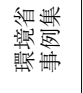 & & & & \\
\hline 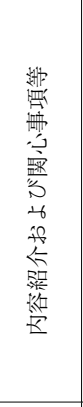 & 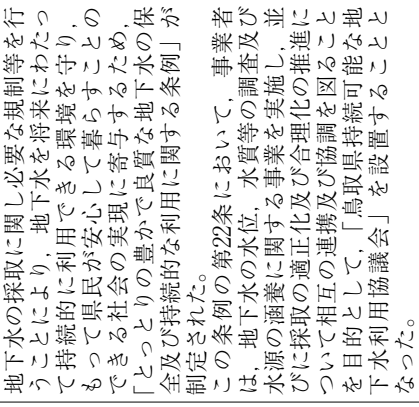 & 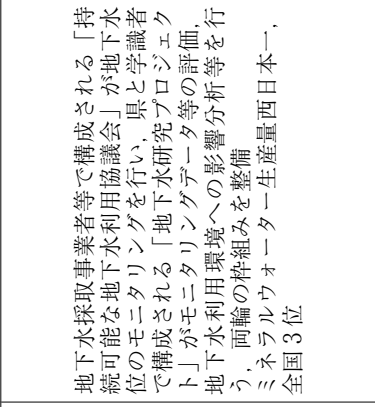 & 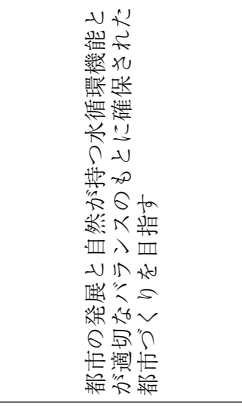 & 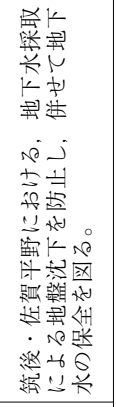 \\
\hline 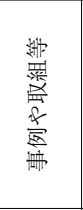 & 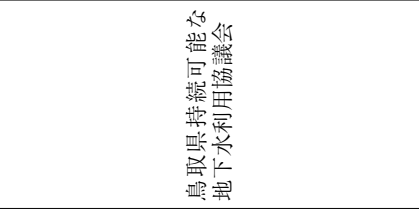 & 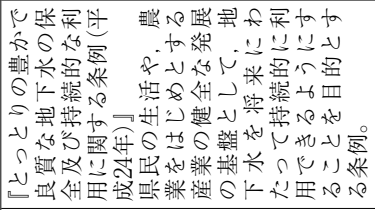 & 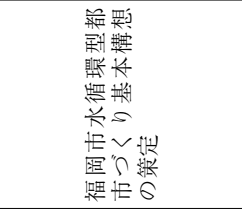 & 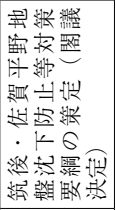 \\
\hline 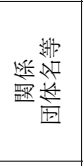 & 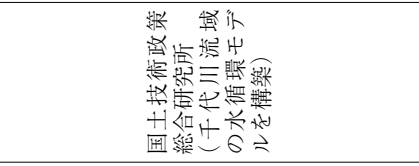 & 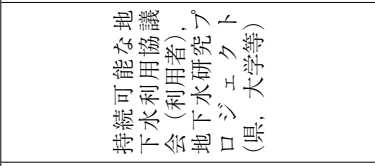 & 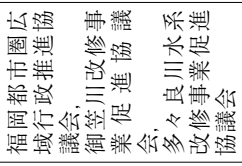 & 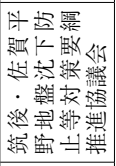 \\
\hline 案 & & 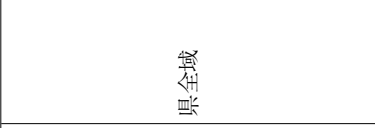 & 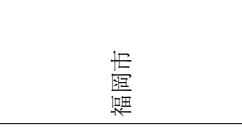 & \\
\hline 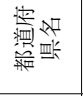 & 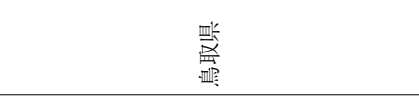 & 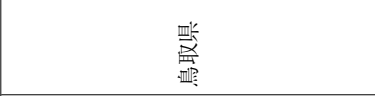 & 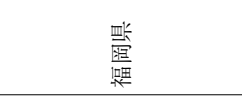 & 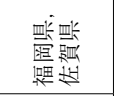 \\
\hline 蛋家 & \&্ & F্ & is & $\vec{\omega}$ \\
\hline
\end{tabular}




\begin{tabular}{|c|c|c|c|c|}
\hline 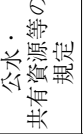 & - & • & • & - \\
\hline $\begin{array}{l}\text { 辣 } \\
\text { 形 }\end{array}$ & & & • & - \\
\hline$\frac{4}{H}$ & ・傩 & 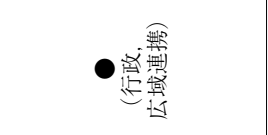 & 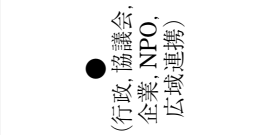 & 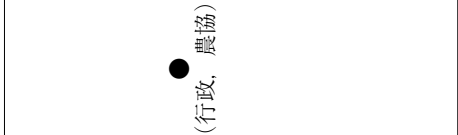 \\
\hline$\frac{\frac{3 \alpha}{H}}{H}$ & - & & • & 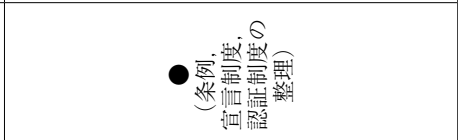 \\
\hline 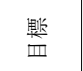 & 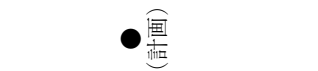 & 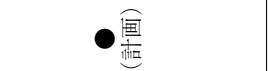 & - 重 & • \\
\hline 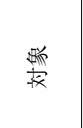 & 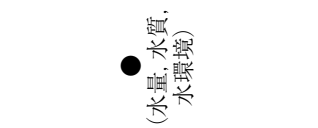 & • 嘅 & ○哭 & 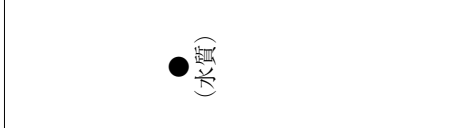 \\
\hline 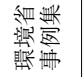 & $\bullet$ & • & $\bullet$ & \\
\hline 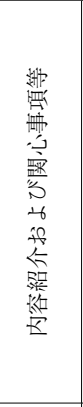 & 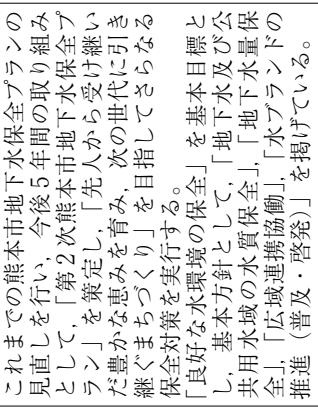 & 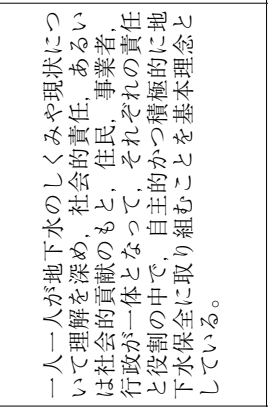 & 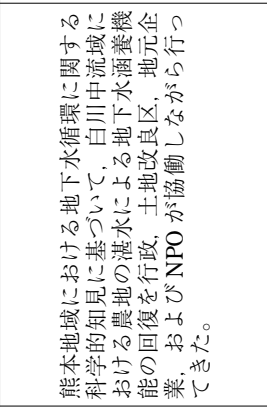 & 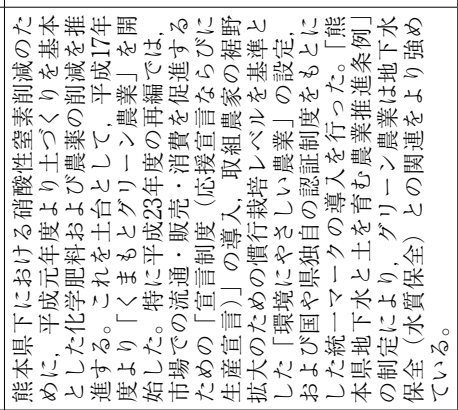 \\
\hline 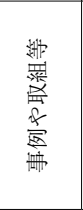 & 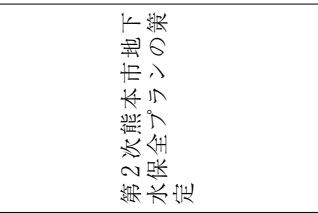 & 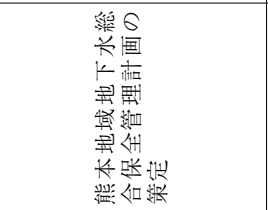 & 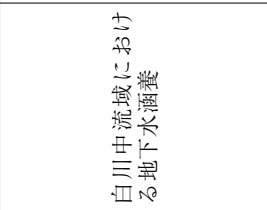 & 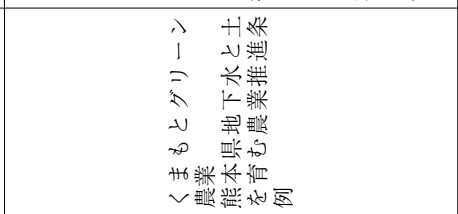 \\
\hline 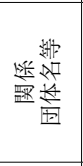 & & 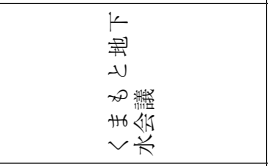 & 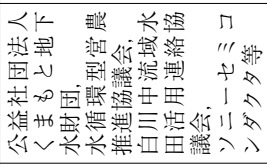 & 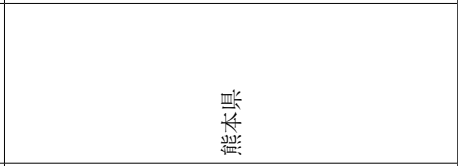 \\
\hline 蜜 & 尘 & 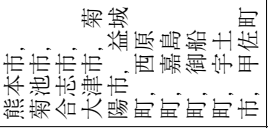 & 蛋 & 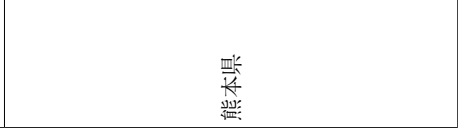 \\
\hline 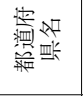 & 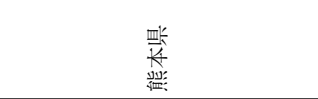 & 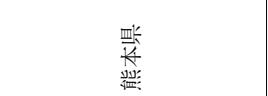 & 誉 & 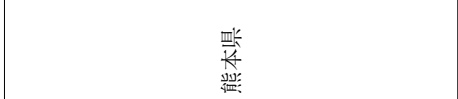 \\
\hline 蛋安 & î & [ึ & 落 & 냉 \\
\hline
\end{tabular}


地下水学会誌 第 62 巻第 2 号 $\quad 233 ２ 54$ (2020)

\begin{tabular}{|c|c|c|}
\hline 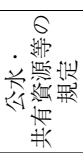 & & \\
\hline 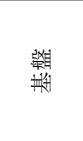 & • & 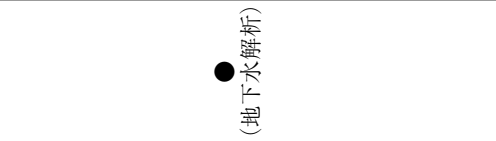 \\
\hline 茀 & • 叒 & 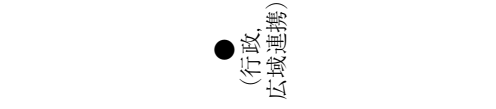 \\
\hline$\frac{\frac{\mathrm{ex}}{\mathrm{m}}}{\mathrm{m}}$ & & \\
\hline 黾 & 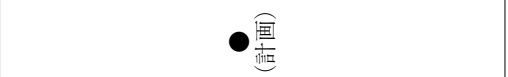 & ○霆 \\
\hline 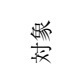 & ○竞 & 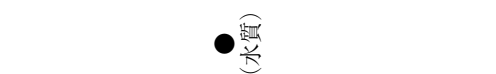 \\
\hline 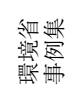 & & \\
\hline 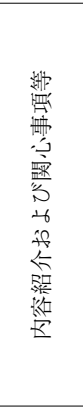 & 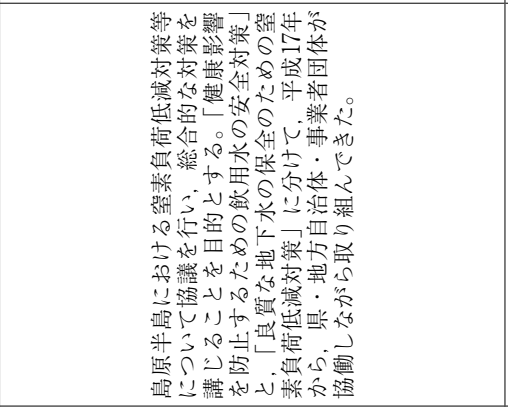 & 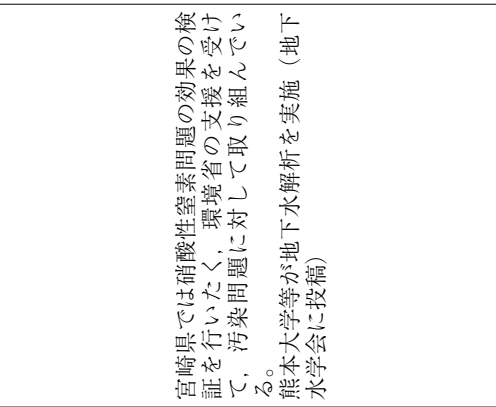 \\
\hline 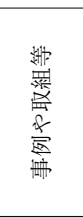 & 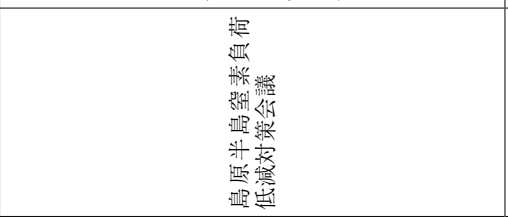 & 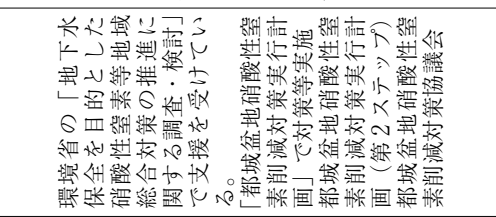 \\
\hline 速 & 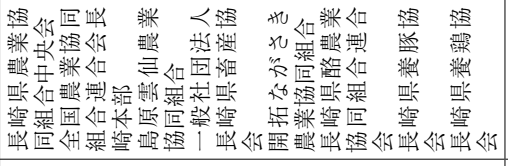 & 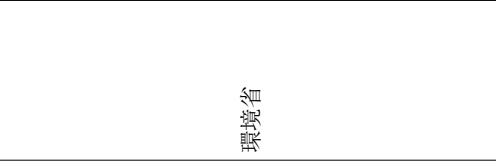 \\
\hline 章 & 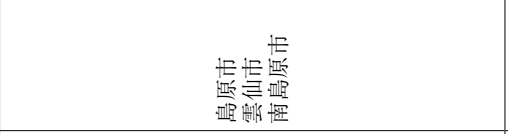 & 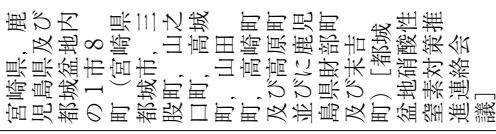 \\
\hline 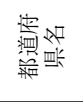 & 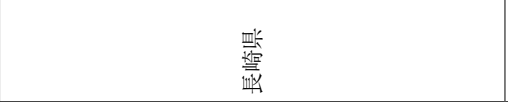 & 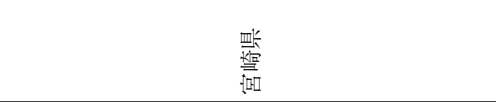 \\
\hline 蛋定 & $i s$ & is \\
\hline
\end{tabular}


地下水学会誌 第 62 巻第 2 号 $\quad 233 \sim 254$ (2020)

\begin{tabular}{|c|c|}
\hline 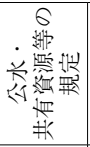 & $\bullet$ \\
\hline 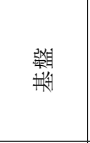 & • \\
\hline$\frac{4}{H}$ & • \\
\hline$\frac{\text { 照 }}{\text { 并 }}$ & 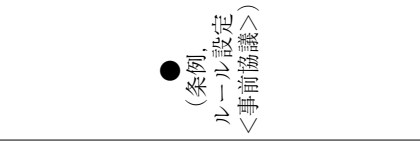 \\
\hline 整 & \\
\hline 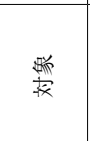 & 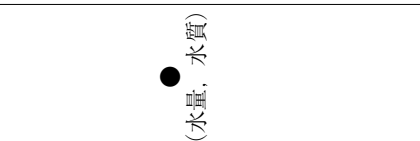 \\
\hline 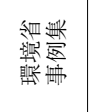 & \\
\hline 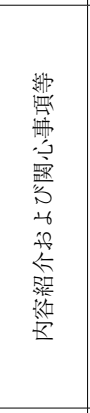 & 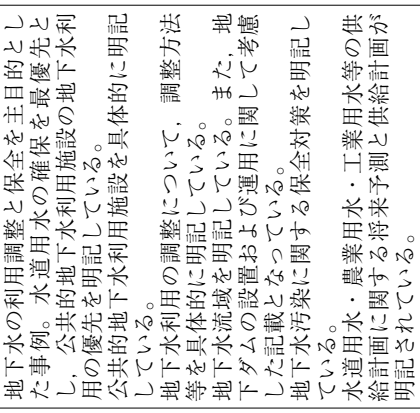 \\
\hline 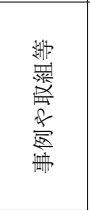 & 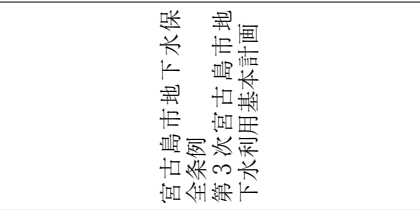 \\
\hline 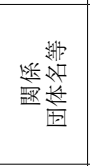 & 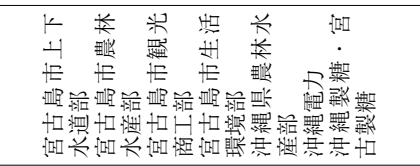 \\
\hline $\begin{array}{l}\text { 案 } \\
\text { 垔 }\end{array}$ & 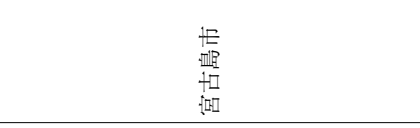 \\
\hline 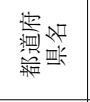 & 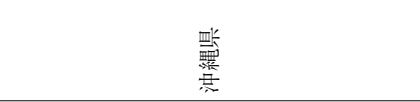 \\
\hline 椣安 & $\stackrel{\infty}{\infty}$ \\
\hline
\end{tabular}


地下水学会誌 第 62 巻第 2 号 $233 \sim 254$ (2020)

組みについて検討を加えてきた。詳細については 八木ほか（2019）を参照いただきたい。この事例 集が, 今後の地下水に関する環境政策や地下水ガ バナンスの展開において参考となれば幸いであ る。

\section{参考文献}

植田和弘（1996）：環境経済学. 岩波書店, 220p.

環境省 (2015)：「地下水保全」事例集～地下水保全と 持続可能な地下水利用のために〜. 環境省水 ·大気
環境局, 106p.

千葉知世（2019）: 日本の地下水政策一地下水ガバナン スの実現に向けて - . 京都大学学術出版会, 355p.

八木信一・中川 啓（2018）：国内関連事例に基づく地 下水ガバナンスの論点整理. 2018年春季講演会講演 予稿, 日本地下水学会, 56-59.

八木信一・遠藤崇浩・坂東和郎 - 中谷 仁 (2020)： 地下水ガバナンスの動態に関する研究一地下水の 社会的価值を分析枠組みとして一. 地下水学会誌,

62 (2), 219-232.

(受付：2019年12月26日, 受理：2020年 1 月22日) 